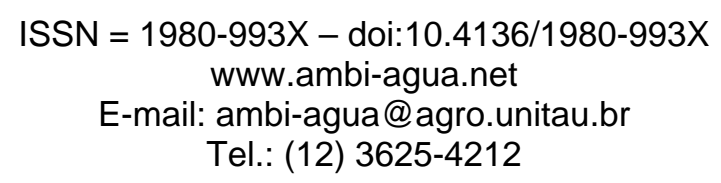

\title{
Carbon and Nitrogen in the Lower Basin of the Paraíba do Sul River, Southeastern Brazil: Element fluxes and biogeochemical processes
}

\author{
(http://dx.doi.org/10.4136/ambi-agua.183)
}

\section{Ricardo de Oliveira Figueiredo ${ }^{1}$; Álvaro Ramon Coelho Ovalle ${ }^{2}$; Carlos Eduardo de Rezende $^{2}$; Luiz Antonio Martinelli ${ }^{3}$}

\author{
${ }^{1}$ Embrapa Meio Ambiente; e-mail: ricfig@cnpma.embrapa.br \\ ${ }^{2}$ Universidade Estadual do Norte Fluminense, Centro de Biociências e Biotecnologia, Laboratório de Ciências \\ Ambientais; e-mails: ramon@uenf.br; crezende@uenf.br \\ ${ }^{3}$ Centro de Energia Nuclear na Agricultura, Universidade de São Paulo; e-mail: martinelli@cena.usp.br
}

\begin{abstract}
The study was conducted in the lower basin of the Paraíba do Sul River (PSR), in which $57,000 \mathrm{~km} 2$ of the basin is located in the Brazilian states of São Paulo, Minas Gerais and Rio de Janeiro. We proposed to identify the main sources of $\mathrm{C}$ and $\mathrm{N}$ fluxes in the PSR waters, to evaluate biogeochemical processes in the watershed, and to estimate $\mathrm{C}$ and $\mathrm{N}$ riverine loads to the Atlantic Ocean in the context of the sugarcane plantation expansion for ethanol production. Riverine water samples were collected at seven stations along 12 months. Physicochemical and limnological parameters, as well as discharge, were measured together with organic and inorganic $\mathrm{C}$ and $\mathrm{N}$ species in the dissolved and suspended particulate material. $\mathrm{C}$ and $\mathrm{N}$ concentrations in bed fluvial sediments, and suspended particulate material were measured, and their elemental $([\mathrm{C}: \mathrm{N}] \mathrm{a})$ and isotopic $(\delta 13 \mathrm{C})$ compositions were compared with the [C:N]a and $\delta 13 \mathrm{C}$ of the following sources: riparian soils, insular flooded soils, aquatic macrophytes, phytoplankton, pasture grass, sugarcane, sugarcane byproducts, and forest litterfall. Temporal patterns in the physicochemical and limnological environment were correlated to discharge. It also was observed that sugar cane production can increase riverine $\mathrm{C}$ and $\mathrm{N}$ fluxes. Riparian soils inputs were larger than insular soils, which was likely to act as a biogeochemical barrier. Effects of the macrophytes on riverine $\mathrm{C}$ and $\mathrm{N}$ were unclear, as well as urban sewage disposal effects. Although the PSR loads represented a very small percentage of the fluvial input to global biogeochemical cycles, we suggest that this and other medium sized watersheds in Eastern and Southeastern South America can be significant contributors to the continental biogeochemical riverine loads to the ocean, if their loads are considered together.
\end{abstract}

Keywords: agriculture; anthropic impacts; biogeochemistry; fluvial loads; river basin.

\section{Carbono e Nitrogênio no Baixo Paraíba do Sul: Fluxos e processos biogeoquímicos}

\section{RESUMO}

Este estudo foi realizado na Bacia do Rio Paraíba do Sul (RPS), cuja área total de $57,000 \mathrm{~km}^{2}$ ocupa setores em três estados brasileiros: São Paulo, Minas Gerais e Rio de Janeiro. $\mathrm{O}$ objetivo deste trabalho foi identificar as principais fontes de $\mathrm{C}$ e $\mathrm{N}$ para as águas do RPS, avaliando os processos biogeoquímicos na bacia e estimando seus aportes de $\mathrm{C}$ e $\mathrm{N}$ para o Oceano Atlântico, no contexto da expansão da lavoura canavieira para a produção de etanol. Ao longo de doze meses foram coletadas amostras de águas fluviais em sete estações 
de amostragem. Foram monitorados nos rios parâmetros fisicoquímicos e limnológicos, assim como vazão e formas orgânicas e inorgânicas de $\mathrm{C}$ e $\mathrm{N}$ no material dissolvido e particulado transportados. Além das concentrações de $\mathrm{C}$ e $\mathrm{N}$ medidas nos sedimentos de fundo e em suspensão foram determinadas as composições elementar ([C:N]a) e isotópica $(\delta 13 \mathrm{C})$ para comparação com [C:N]a and $\delta 13 \mathrm{C}$ das seguintes fontes potenciais de material orgânico: solos ripários, solos insulares inudáveis, macrófitas aquáticas, fitoplancton, gramíneas de pastagens, cana-de-açúcar, subprodutos da produção sucroalcooleira, e a serapilheira florestal. Padrões temporais no ambiente fisicoquímico e limnológico foram correlacionados à magnitute das vazões. Também se observou que a produção sucroalcooleira tem potencial de aumentar os fluxos de $\mathrm{C}$ e $\mathrm{N}$ nos rios dessa bacia. A contribuição por solos ripários foram maiores do que a dos insulares, os quais parecem funcionar como barreira biogeoquímica. Da mesma maneira que o esgoto urbano, os efeitos das macrófitas no $\mathrm{C}$ e $\mathrm{N}$ fluvial não foram claros. Embora as cargas do RPS representem um percentual muito pequeno na contribuição fluvial para os ciclos biogeoquímicos globais, sugere-se que esta e outras bacias de média escala no leste e sudeste da América do Sul, caso consideradas em conjunto, são contribuintes relevantes para as cargas continentais biogeoquímicas para o oceano.

Palavras-chave: agricultura; bacia hidrográfica; biogeoquímica; cargas fluviais; impactos antrópicos.

\section{INTRODUCTION}

The transport of terrestrial carbon $(\mathrm{C})$ and nitrogen $(\mathrm{N})$ into and within rivers, eventually to the oceans, is an important stage in the global cycle of these elements. As a result of increasing environmental problems at local, regional and global scales, there is an increasing interest in biogeochemical sciences, particularly their relationships with these problems. Climate changes, for instance, are partly caused by the increase of $\mathrm{C}$ and $\mathrm{N}$ fluxes in biogeochemical cycling largely as a function of anthropogenic activities (Degens et al. 1991, Jordan and Weller, 1996; Mackenzie et al. 1993; Richey et al. 1990; Vitousek, 1994).

One of the main scientific challenges in studying watersheds is to determine how the hydrological and biogeochemical cycles function at the terrestrial surface, where watersheds play the role of natural integrators of several related processes (Richey and Victoria, 1993). However, the estimates of global $\mathrm{C}$ and $\mathrm{N}$ fluxes have been restricted to scientific studies that were either conducted in the largest basins of the world or in small catchments (Hedges, 1992; Meybeck, 1993; McClain and Elsenbeer, 2001; Richey et al. 2002), with very few exceptions. This fact demonstrates an important gap in biogeochemical cycling studies, particularly land use changes in medium-sized river basins.

Terrestrial elemental fluxes in a watershed are governed by biotic and abiotic factors. Such processes occur between vegetation and soil, with elements partly retained in the system and partly exported through atmospheric losses, superficial and sub-superficial runoff, and lixiviation until exit in drainage waters (Moldan and Cerný, 1994). Investigations of these processes, mainly in tropical and subtropical areas, are scarce, and are greatly needed in order to understand the effects of land use changes, such as deforestation, on elemental dynamics and movement. Two elemental components, the carbon isotopic composition $\left(\delta^{13} \mathrm{C}\right)$ and the elemental composition $(\mathrm{C}: \mathrm{N})_{a}$, can be used as tracers of organic matter sources to identify and monitor such changes (Hedges, 1990).

One area that has experienced significant deforestation for centuries has been an extensive area of tropical forest along the Brazilian coast, called the Atlantic Forest. Deforestation, vegetation loss, landscape change, and urban development have dramatically altered the biogeochemical cycling of this area, including increased amount of the material exported by the rivers and its respective basins (Brasil, 1995). 
One of the main rivers in the Atlantic Forest area, the Paraíba do Sul River (PSR), has experienced significant environmental changes and degradation, largely through industrial pollution, domestic sewage, urban garbage, non-point inputs from agriculture, dams for water use and energy, mining of gold and sand, and deforestation at its headwaters and along riparian areas, among other impacts. Additionally, in the northern part of the state of Rio de Janeiro, the waters of the PSR and its tributaries are used for public provisioning. As a result of this environmental degradation there is a need to increase the amount of studies focused on elemental dynamics that may affect the quality of water resources, as well as carbon and nitrogen cycling (Costa, 1994).

In this work, we analyzed the fluxes and export of carbon and nitrogen in the PSR basin. Despite field collection and lab analysis having been conducted more than ten years ago, this research at this medium-sized river basin provides information relevant to current environmental concerns in the region, particularly the response of riverine water to patterns of land use change related to sugar cane production for ethanol production (Ballester et al. 2010).

The objectives of the present study are three: $i$. Identify the main sources of natural and anthropogenic inputs to the fluvial $\mathrm{C}$ and $\mathrm{N}$ fluxes in the Lower Paraíba do Sul River Basin; ii. Evaluate the biogeochemical processes that drive the cycling of these elements in the watershed; and iii. Estimate the watershed loads to the South Atlantic Ocean. We hypothesized that sugar cane production has the potential to substantially change the riverine $\mathrm{C}$ and $\mathrm{N}$ fluxes.

\section{MATERIAL AND METHODS}

\subsection{Study area}

This research was conducted in the lower basin of the Paraíba do Sul River (PSR); the PSR flows through part of three Brazilian states - São Paulo, Minas Gerais, and Rio de Janeiro (Figure 1). The PSR basin, together with other small and medium sized river basins, constitutes the entire hydrographic system of the eastern Brazilian region draining to the South Atlantic Ocean.

The lower basin of the PSR occupies $22,400 \mathrm{~km}^{2}$ of the total $57,000 \mathrm{~km}^{2}$ of the entire basin, and includes three important tributary watersheds: Pomba $\left(9,180 \mathrm{~km}^{2}\right)$, Muriaé $\left(8,140 \mathrm{~km}^{2}\right)$ and Dois Rios $\left(3,530 \mathrm{~km}^{2}\right)$ watersheds (Table 1 and Figure 2). The lower reach of the PSR begins after the river has left a mountainous region (elevations from 500 to $1,800 \mathrm{~m}$ ) to cross a large plain with smooth elevations (elevations less than $520 \mathrm{~m}$ ). The presence of floodplains increases downstream, and as the PSR nears the ocean, near the city of Campos dos Goytacazes, it crosses a large coastal lowland area. In the lowland area altitude is less than $20 \mathrm{~m}$ and the declivity is almost zero. At this point of the river, there are many fluvial islands that are flooded, along with the riparian zones, during high flow periods (Costa, 1994; Brasil, 1995; 1983).

The geology of the PSR basin is classified as predominantly ancient Pre-Cambrian and Tertiary lands, but the delta in the coastal lowland has a more recent origin (Tertiary and Quaternary periods). The original eutrophic soils became depleted of nutrients due to coffee plantations and cattle pastures that replaced the original dense tropical forest (Atlantic Forest) covering the entire area; the only remnants of Atlantic Forest are at the tops of the highest mountains. According to Brazilian soils classification the predominant soils in the area are Latossolos, but there are also Argissolos and Cambissolos, as well as alluvial and hydromorphic soils (Neossolos) in the coastal lowland (Costa, 1994; Brasil, 1995; 1983). 
FIGUEIREDO, R. de O.; OVALLE, A. R. C.; REZENDE, C. E. de.; MARTINELLI, L. A. Carbon and Nitrogen in the Lower Basin of the Paraíba do Sul River, Southeastern Brazil: Element fluxes and biogeochemical processes. Ambi-Agua, Taubaté, v. 6, n. 2, p. 7-37, 2011. (doi:10.4136/ambi-agua.183)

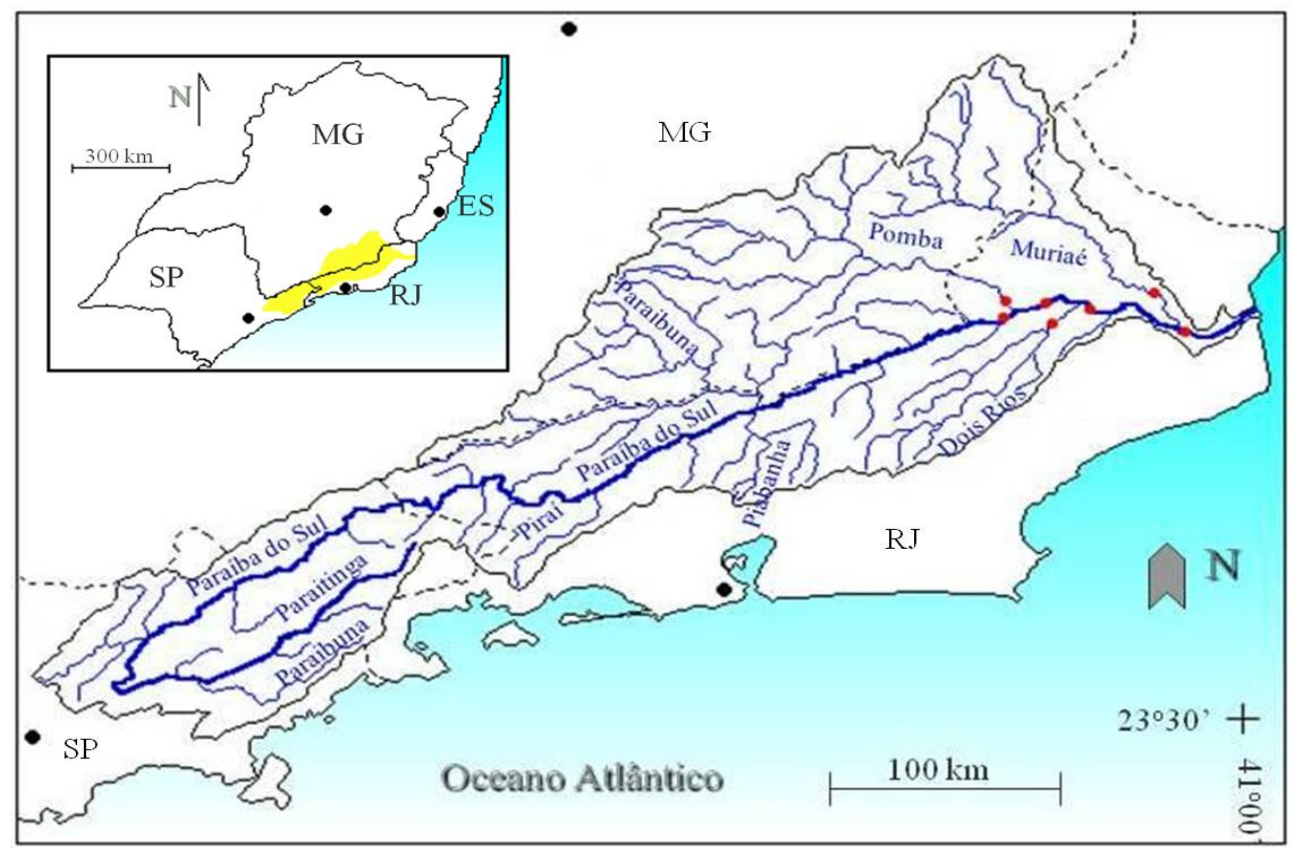

Figure 1. Location of the Paraíba do Sul River Basin in relation to four Southeast Brazilian states $(\mathrm{MG}=$ Minas Gerais; $\mathrm{SP}=$ Sao Paulo; $\mathrm{RJ}=$ Rio de Janeiro; and ES $=$ Espirito Santo). Capitals are marked as black points, and the yellow area denotes the river basin. The detailed map shows the main tributaries and sampling stations (as red circles) located in the lower portion of the basin.

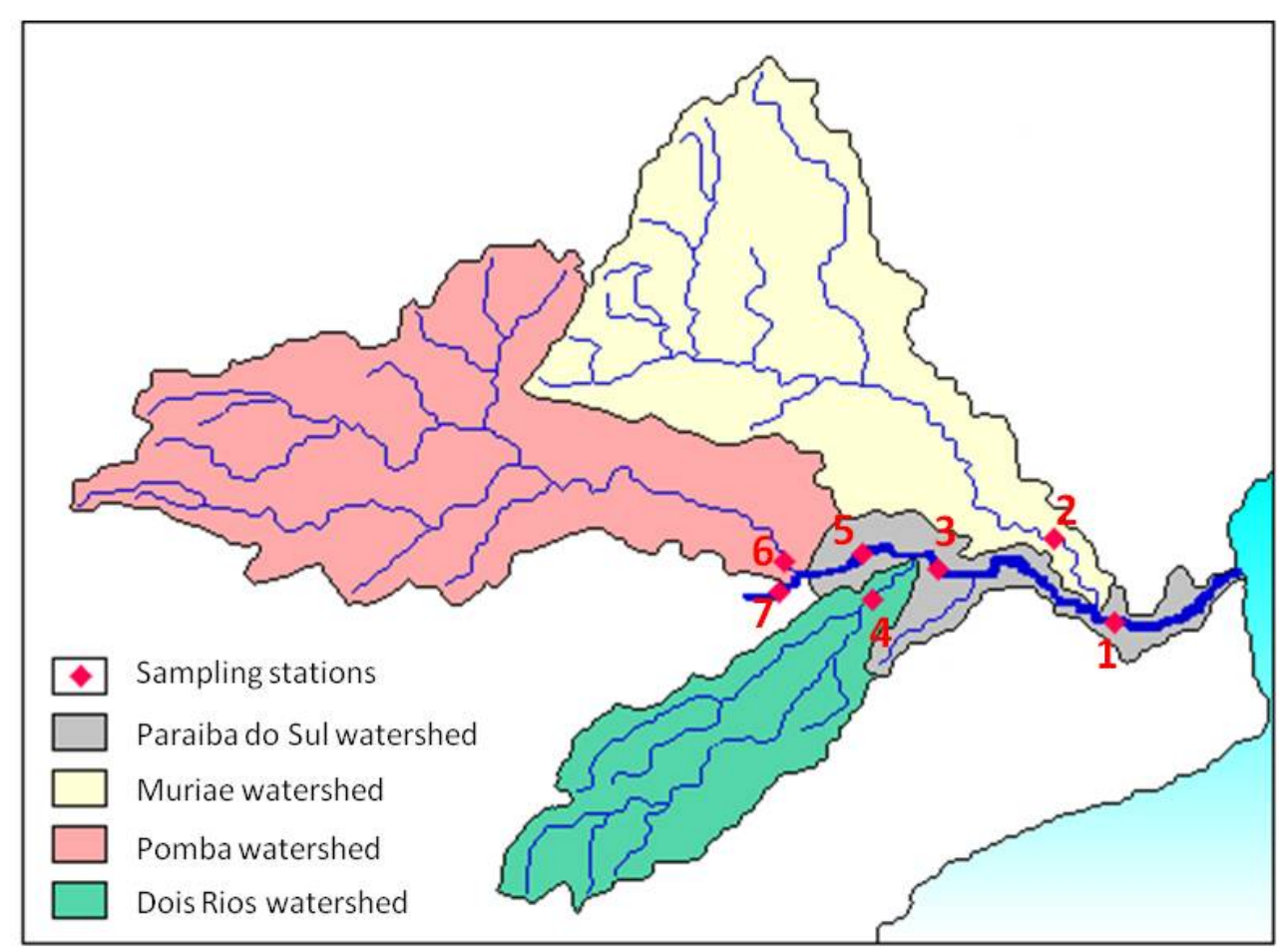

Figure 2. The lower portion of the Paraíba do Sul River Basin, including the watershed areas of the three studied tributaries and the locations of the seven sampling stations.

The range of annual precipitation in the river basin is very large (1000 to $3000 \mathrm{~mm})$, but in the PSR lower basin, annual average precipitation is close to the minimum value of this range. Rains are more intense during summer. Due to different altitudes, the basin 
experiences great variability in temperature. In the lower basin of the PSR, temperatures are high (maximum average $=32-34^{0} \mathrm{C}$; minimum average $=15-17^{0} \mathrm{C}$ ). The large use of water on irrigation or by hydroelectric plants, industries and cities greatly affect the discharge of the PSR. The PSR annual average discharge measured from 1988 to 1993 in Campos dos Goytacazes by DNAEE was about $900 \mathrm{~m}^{3} \mathrm{~s}^{-1}$.

Table 1. Sampling station geographic locations and their respective drainage areas. (PSR = Paraíba do Sul River).

\begin{tabular}{|c|c|c|c|c|}
\hline $\begin{array}{l}\text { Station } \\
\text { number }\end{array}$ & Station name & Latitude & Longitude & $\begin{array}{c}\text { Drainage } \\
\text { area }\left(\mathrm{km}^{2}\right)\end{array}$ \\
\hline 1 & PSR/Campos & $21^{\circ} 45^{\prime} 06^{\prime \prime} \mathrm{S}$ & $41^{\circ} 19^{\prime} 32^{\prime \prime} \mathrm{W}$ & 57,000 \\
\hline 2 & Rio Muriaé & $21^{\circ} 35^{\prime} 15^{\prime \prime} \mathrm{S}$ & $41^{\circ} 26^{\prime} 17^{\prime \prime} \mathrm{W}$ & 8,139 \\
\hline 3 & $\begin{array}{l}\text { PSR/ São } \\
\text { Fidélis }\end{array}$ & $21^{\circ} 38^{\prime} 44^{\prime \prime} \mathrm{S}$ & $41^{\circ} 44^{\prime} 46^{\prime \prime} \mathrm{W}$ & 48,090 \\
\hline 4 & Rio Dois Rios & $21^{\circ} 42^{\prime} 55^{\prime \prime} \mathrm{S}$ & $41^{\circ} 55^{\prime} 36^{\prime \prime} \mathrm{W}$ & 3,529 \\
\hline 5 & PSR/Cambuci & $21^{\circ} 35^{\prime} 24^{\prime \prime} \mathrm{S}$ & $41^{\circ} 55^{\prime} 50^{\prime \prime} \mathrm{W}$ & 44,561 \\
\hline 6 & Rio Pomba & $21^{\circ} 37^{\prime} 47^{\prime \prime} \mathrm{S}$ & $42^{\circ} 05^{\prime} 17^{\prime \prime} \mathrm{W}$ & 9,183 \\
\hline 7 & PSR/Itaocara & $21^{\circ} 38^{\prime} 45^{\prime \prime} \mathrm{S}$ & $42^{\circ} 05^{\prime} 06^{\prime \prime} \mathrm{W}$ & 34,993 \\
\hline
\end{tabular}

Nonpoint source pollution from agriculture, mainly sugarcane agriculture and cattle ranching, is more prevalent in the lower portion of the study river basin than in the upper basin. Other important sources, that impact the riverine waters include deficiency or lack of treatment of sewage, industrial refuse disposal, urban garbage, soil erosion, and mine activities (gold and sand). Ovalle et al. (1997) suggested that sugarcane crop activities, such as burning, harvest, tillage, fertilization and irrigation, together with sewage inputs, are the most important nutrient sources to the lower reach of the PSR, in which higher nutrient concentrations are observed during low discharge periods. Other studies conducted in the area have stressed the importance of anthropogenic sources of nutrients, heavy metals, organic compounds and sediments as inputs into the tributaries the basin (Carvalho et al. 1995; Carvalho, 1997; Costa, 1994; Costa and Freitas, 1989; Brasil, 1995; Lacerda et al. 1993; Salomão, 1997).

\subsection{Sampling, in situ measurements and stations locations}

Fieldwork was conducted for the period of one year, from January $21^{\text {st }}, 1997$ to January $30^{\text {th }}, 1998$. The output point of the PRS, named Station 1, was located in the city of Campos dos Goytacazes (Figure 2) and was where we conducted bimonthly sampling of river water. Six additional sampling stations also were selected (Table 1 and Figure 2), but at these sampling points, we conducted only three sampling field campaigns, one at each discharge magnitude period (low, medium and high discharges). At these six stations, as it is detailed in item 2.4, we were able to roughly estimate $\mathrm{C}$ and $\mathrm{N}$ fluxes of the three main sub-basins of the PSR lower basin (Muriaé, Pomba, and Dois Rios), as well as $\mathrm{C}$ and $\mathrm{N}$ fluxes of the PSR at the stations located upstream of each sub-basin output.

Four in situ physicochemical measurements $-\mathrm{pH}, \mathrm{E}_{\mathrm{H}}$, electric conductivity (EC) and temperature $(\mathrm{T})$ - were taken at each sampling station using portable equipment (Digimed 
$D M-P V$ and WTW model LF96). Using a plastic bucket, we collected superficial water for total suspended sediments (TSS) quantification as well as for dissolved oxygen, chlorophyll $a$ and pheopigment analysis. In three volumetric glass bottles, magnesium chloride and an alkaline potassium iodide solution were added to sample aliquots for oxygen fixing. Moreover, for chlorophyll $a\left(\mathrm{Chl}_{a}\right)$ and pheopigment (Pheo) analyses, we collected water samples into three polyethylene bottles.

For carbon and nitrogen analyses, water samples were collected along the river water column by submerging an open 4 liter amber glass bottle tied to a heavy anchor to ensure sufficient depth to sample the entire water column. We repeated this procedure until we collected 50 liters of water, which were stored in five $10 \mathrm{~L}$ polyethylene bottles. Additionally, sub-samples were taken for suspended sediments, total alkalinity (Alk), total dissolved nitrogen (TDN), and dissolved organic carbon (DOC) analysis. All sample aliquots were stored in ice boxes until analysis in the lab.

Riparian and insular soils samples $(0-10 \mathrm{~cm}$ depth) were collected using a soil auger. For bed sediment $(<2 \mathrm{~cm}$ depth) sampling, we used a small boat in the dry season when, along the channel edges, bed sediments were exposed but still wet, so that they could be easily collected using a small plastic paddle. Aquatic macrophytes were collected at 27 points along the edges of the PSR, including mangrove areas at the river estuary (Figure 3).

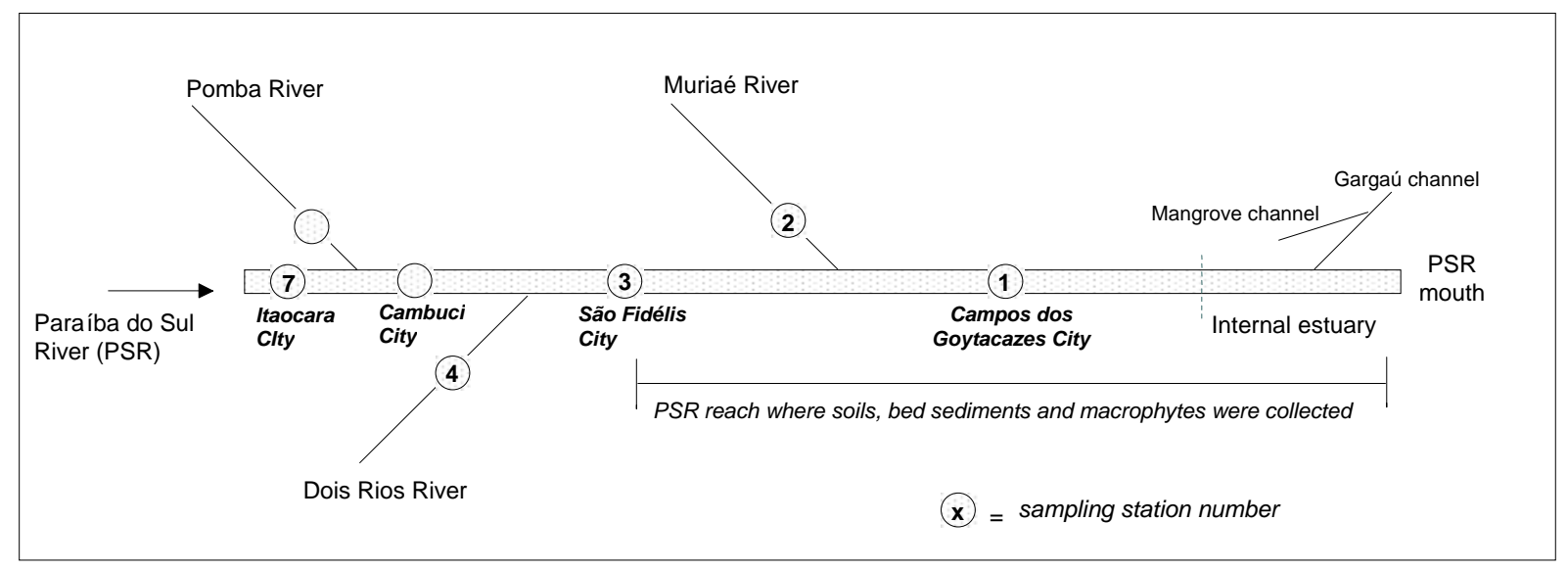

Figure 3. Sample design: Seven water and suspended sediment sampling stations and a reach of the Paraíba do Sul River where riparian soils, bed sediments and macrophytes samples were collected.

\subsection{Laboratory procedures}

Samples collected for dissolved oxygen (DO) were analyzed by the Winkler method (Golterman et al. 1978). Samples for chlorophyll a (Chla) and pheopigment (Pheo) were vacuum filtered through glass fiber membranes (Whatman $\mathrm{GF} / \mathrm{F}$ ) using $250 \mathrm{ml}$ aliquots and extraction with ethanol $95 \%$, at $\sim 80^{\circ} \mathrm{C}$ for later spectrophotometry reading (Golterman et al. 1978; Nush and Palme, 1975). Total alkalinity (Alk) analyses were conducted by the Gran titration method (Gran, 1952) using a Mettler DL21 automatic titrator.

For dissolved $\mathrm{C}$ and $\mathrm{N}$ analysis, water samples were vacuum filtered through glass fiber membranes (Whatman GF/F) and kept frozen in polyethylene bottles until analysis. For dissolved organic carbon (DOC), two replicates of each filtered sample were preserved with $10 \%$ phosphoric acid and kept refrigerated $\left(4^{\circ} \mathrm{C}\right)$ in amber glass bottles until analysis (Sharp et al. 1993). Dissolved inorganic carbon (DIC) was calculated by entering the alkalinity and $\mathrm{pH}$ values in the CARBODOCE software (Carmouze, 1994).

DOC was determined by high temperature catalytic oxidation using a Shimadzu TOC5000. The determination of nitrate $\left(\mathrm{NO}_{3}^{-} \mathrm{-N}\right)$ and nitrite $\left(\mathrm{NO}_{2}^{-}-\mathrm{N}\right)$ was performed colorimetrically using an injection flux automatic system (ASIA-Ismatec). Ammonium $\left(\mathrm{NH}_{4}{ }^{+}-\right.$ 
N) was determined through the indophenols colorimetric method. Dissolved organic nitrogen (DON) was determined by calculating the difference between total dissolved nitrogen (TDN) and dissolved inorganic nitrogen (DIN), with TDN determined by the colorimetric method from flux injection analysis, but only after persulfate digestion of samples (Golterman et al. 1978).

To quantify coarse and fine fractions (CSS and FSS) of the total suspended solids (TSS) material we used the following procedures (adapted from Meade, 1985):

1. Water samples from the five $10 \mathrm{~L}$ bottles were sieved in a $63 \mu \mathrm{m}$ mesh sieve.

2. The CSS retained in the sieve were collected by a Pasteur pipette, dried in an oven at $40^{\circ} \mathrm{C}$, ground and kept in glass vials until the analysis.

3. Water that had been passed through the sieve was then transferred back to the $10 \mathrm{~L}$ bottles for storage for 72 hours in an ice box.

4. The supernatant was placed into a centrifuge (Hitachi model Himac CR21) at 8,500 $\mathrm{rpm}$ and $17^{\circ} \mathrm{C}$. These FSS samples were dried at $40^{\circ} \mathrm{C}$, ground and kept in glass vials until the analysis.

The suspended particulate material recuperation efficiency by this process was determined for each sampling campaign comparing such results with TSS values that were determined by gravimetric method (Martinelli et al., 1993) using Millipore membranes $(\varnothing=$ $45 \mu \mathrm{m})$. Station 1 presented a recuperation efficiency of $98 \%(\mathrm{n}=26)$, while the other stations presented $89 \%$ of efficiency $(n=18)$.

Soil and bed sediment samples were dried in a circulated oven at $40^{\circ} \mathrm{C}$, and then dry sieved ( $2 \mathrm{~mm}$ mesh) to eliminate any undesirable coarser material. Afterwards, the samples were wet sieved using stainless steel sieves $(63 \mu \mathrm{m}$ mesh) to separate coarse and fine fractions. Finally, samples were ground and stored in glass vials until analysis. The plant samples, after being dried at $40^{\circ} \mathrm{C}$, were chopped in a knife mill and then stored in glass vials until the analysis.

Total organic carbon (TOC) and total nitrogen (TN) in the solid samples were measured by combustion using a CHNS/O Perkin Elmer 2400 Series II with an attached automatic weighing scale. $\delta^{13} \mathrm{C}$ content in the solid samples was then analyzed by mass spectrometry in a laboratory at CENA in the São Paulo University. The isotopic ratio ${ }^{13} \mathrm{C} /{ }^{12} \mathrm{C}$ of the samples was compared to the PDB (Belemnitela americana) standard and expressed in parts per thousand $(\% 0)$ of $\delta^{13} \mathrm{C}$ (Martinelli et al. 1988).

\subsection{Discharge and mass fluxes measurements}

To measure current speed at different depths ( 1 meter below the surface, at the middle of the water column, and 1 meter above the bottom), we used flowmeters (General Oceanic model 2030) to calculate the instantaneous discharge for each sampling station.

For Station 1 (PSR/Campos), the discharge curve was developed from 26 sample measurements collected in this study (1997-98). To create the discharge curves of stations 3 to 6, where we only had 3 sample measurements, we used data collected by DNAEE in 199798. As DNAEE did not have discharge data for Station 7 (PSR/Itaocara) and Station 2 (Muriaé), we used data from 1994-96 collected by Universidade Estadual do Norte Fluminense. As a result, the total number of measurements used to generate the discharge curves varied from 13 to 31 among all sampling stations. Using the discharge curves and the daily DNAEE depth data, we calculated daily discharges for each of the seven sampling stations.

To estimate mass fluxes at the output of the PSR basin (Station 1), due to the lack of daily water chemistry data, we had to considere that the element concentrations were constant between two sampling dates and multiplied these concentrations by the daily estimated 
discharge to obtain the daily mass fluxes of each element. These daily mass fluxes were added together to obtain the annual mass fluxes. Classification of discharge magnitude periods was performed for each of the seven stations by determining the lower and upper limits of each discharge magnitude period at each station through use of frequency histograms and calculations performed using Statistica StatSoft software.

\subsection{Statistics approach}

We used Systat ${ }^{\circledR}$ for Windows ${ }^{\circledR}$ version 11 software to perform statistical analysis. Data was tested for normality, and the following variables were found to have a normal distribution: $\mathrm{pH}, \mathrm{E}_{\mathrm{H}}$, temp, EC, DO, Pheo, Alk, DIC, DOC, $\mathrm{NO}_{3}{ }^{-}-\mathrm{N}, \mathrm{CPC}, \mathrm{FPC}, \mathrm{TPC}, \mathrm{CP}$ $\delta^{13} \mathrm{C}$, FP $\delta^{13} \mathrm{C}$, and TP $\delta^{13} \mathrm{C}$. Because other variables were not found to have normal distribution, we used means and standard deviations in analysis and used nonparametric statistical tests, such as the Spearman correlation coefficient, to test correlations among the variables.

\section{RESULTS AND DISCUSSION}

\subsection{Riverine hydrology trends}

During the study period, discharge at Station 1 ranged from 402 to $2,351 \mathrm{~m}^{3} \mathrm{~s}^{-1}$, with annual mean and standard deviation equal to 872 and $416 \mathrm{~m}^{3} \mathrm{~s}^{-1}$, respectively. Based on the 1934-1992 temporal series (Costa, 1994), the study period was a typical hydrological year. Among the studied tributaries, annual mean discharge estimates were higher in the Pomba River $\left(116 \mathrm{~m}^{3} \mathrm{~s}^{-1}\right)$, followed by the Muriaé River $\left(87 \mathrm{~m}^{3} \mathrm{~s}^{-1}\right)$ and Dois Rios River $\left(38 \mathrm{~m}^{3} \mathrm{~s}^{-1}\right)$.

Based on the Station 1 measurements and the historical data series, we inferred three discharge classes: low $\left(<600 \mathrm{~m}^{3} \mathrm{~s}^{-1}\right)$, medium $\left(600-1200 \mathrm{~m}^{3} \mathrm{~s}^{-1}\right)$, and high $\left(>1200 \mathrm{~m}^{3} \mathrm{~s}^{-1}\right)$. In this study, the medium discharge period accounted for $44 \%$ of the year, while low and high discharges periods corresponded to $37 \%$ and $19 \%$, respectively.

As shown in Figure 4, the present study began during a high discharge period, which continued until late March, when medium flows predominated until the beginning of a low discharge period in June, which extended until November. High flows returned in December and continued until January 1998, completing one hydrological year.

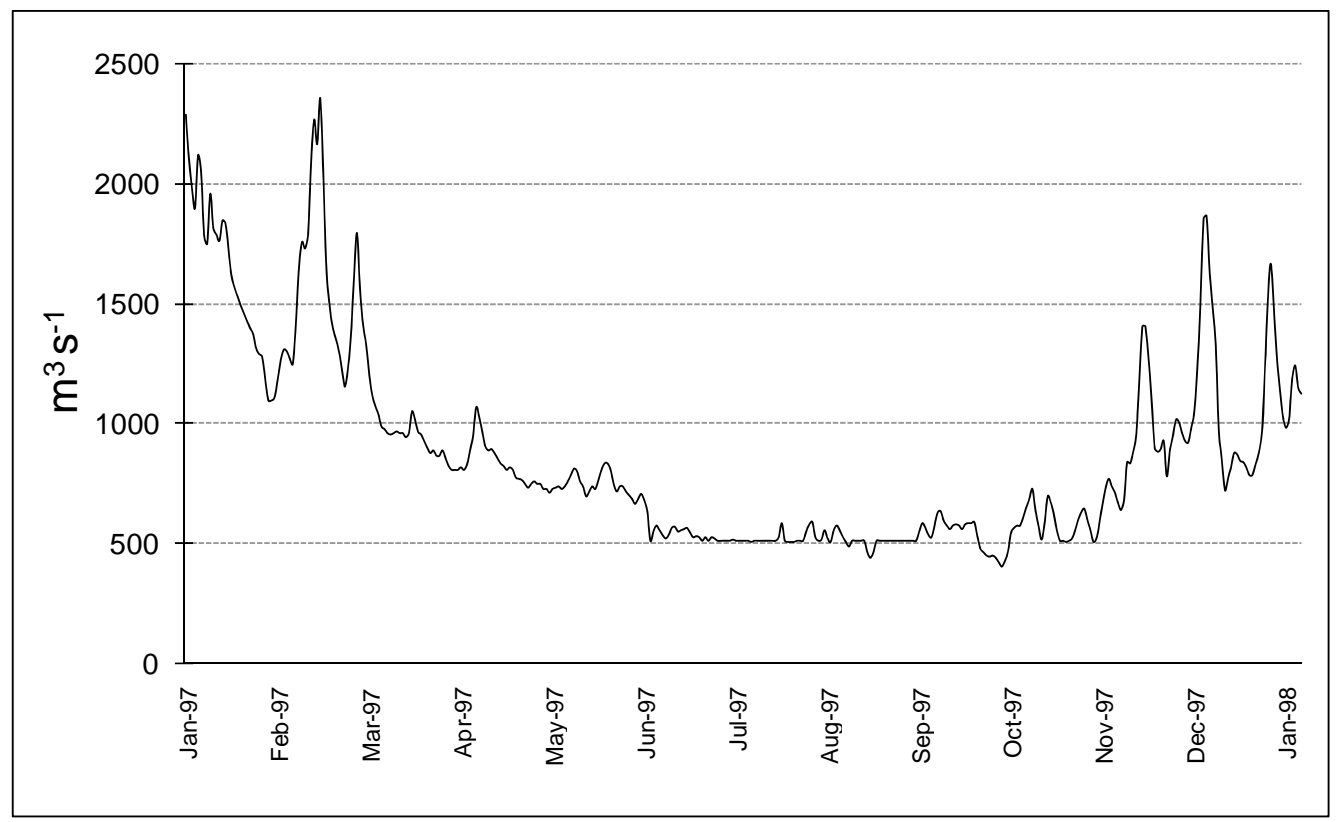

Figure 4. Daily discharge $\left(\mathrm{m}^{3} \mathrm{~s}^{-1}\right)$ in the Paraíba do Sul River at Station 1. 


\subsection{Riverine physicochemical and limnological trends}

As shown in Figure 5, in which the average values of all physicochemical and limnological parameters measured at Station 1 in the three different discharge periods (high, medium and low), the highest $\mathrm{T}$ values were observed during the summer, which corresponds to the high discharge period, while low temperatures were observed during the winter, which corresponds to the low discharge period. On the other hand, EC increased with a decrease in discharge, a statistically inverse correlation $\left(\mathrm{r}_{\mathrm{S}}=-0.726 ; \mathrm{p}<0.01\right)$, which reflects the dilution of ions as a result of increase discharge. Even the temporal variation in conductivity was not very large, with very few high values; during low discharge, the largest amount of total ionic content $(\mathrm{EC}=84.0 \mu \mathrm{S}$ in September) was present, largely due to biogeochemical processing in warm riverine environments (Rimawi et al. 1992; Devol et al. 1995). For $\mathrm{pH}$, we found a temporal trend of lower values during the high discharge period, confirmed by a negative correlation $\left(\mathrm{r}_{\mathrm{S}}=-0.689 ; \mathrm{p}<0.01\right)$. Also Alk tended to decrease as discharge increased. Our results also follow similar trends as reported by other studies at Station 1 (PSR/Campos) conducted from 1994 to 1996 (Carvalho et al. 1995; Ovalle et al. 1997; Silva, 1997), in which some of the patterns were: (1) Both $\mathrm{pH}$ and EC inversely related with discharge; (2) Water temperature with similar annual range and mean. As a result, this studied period represents a typical year of the studied river basin.

At Station 1, pH ranged from 6.86 to 8.15 , reflecting a neutral to slightly alkaline riverine aquatic environment. This physicochemical trend, in which the mean annual $\mathrm{pH}$ was 7.46 , can be also affected by dolomite mineral from rocks of the middle section of the PSR Basin, where weathering contributes to the bicarbonate flux, as well as from some marble rocks in the Muriaé River Basin which contributes, by weathering, calcite to the flux of bicarbonate, thereby increasing $\mathrm{pH}$ and Alk of the river waters (Brasil, 1983). Mineral weathering sources are more important during low discharge, as groundwater inputs are larger compared to surface and sub-surface flowpaths. As a consequence, $\mathrm{HCO}_{3}^{-}$, an important by-product of weathering reactions, increases its concentration in response to a smaller dilution.

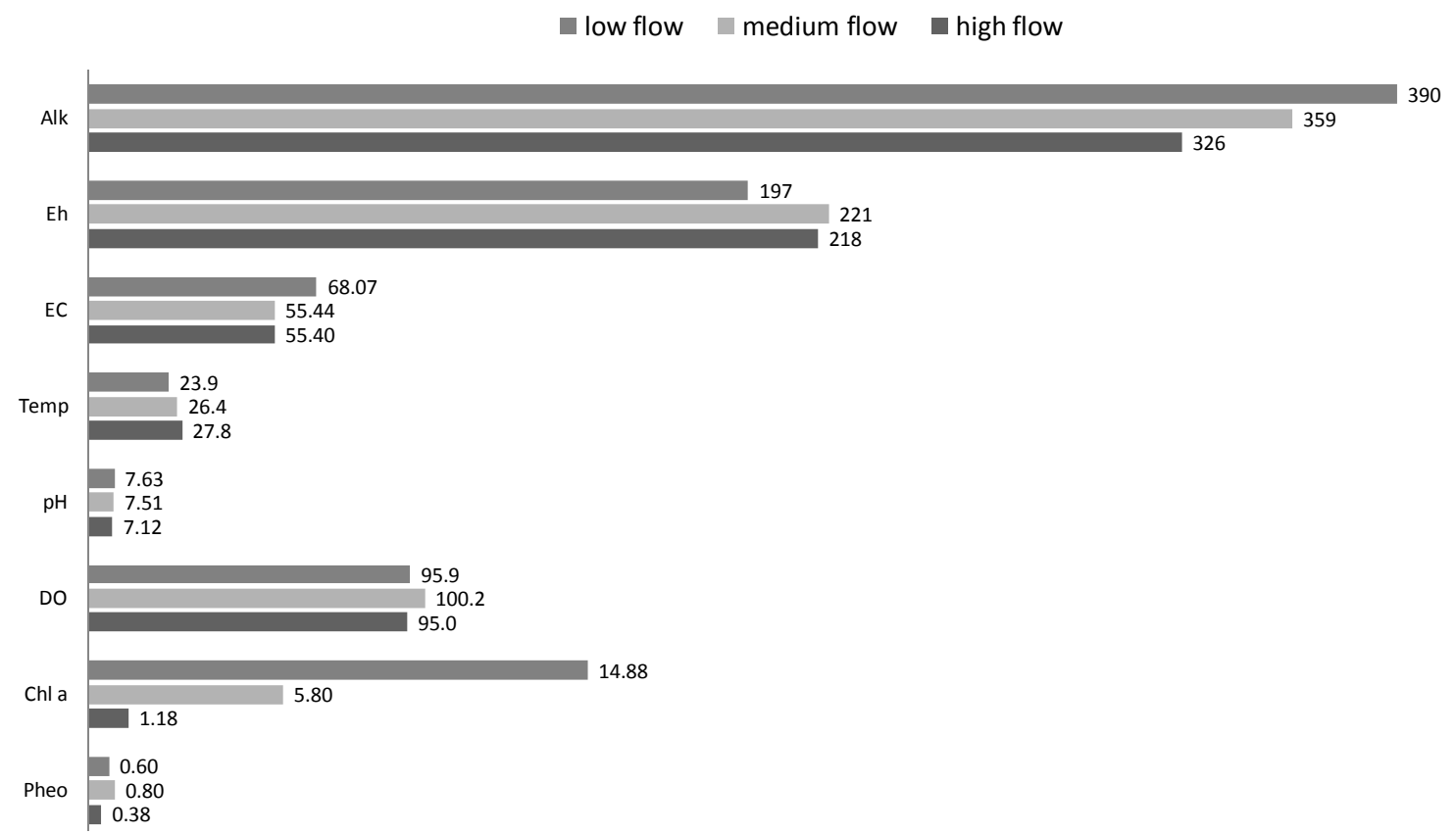

Figure 5. Mean values of physiochemical parameters - alkalinity (Alk) in $\mu \mathrm{Eq} \mathrm{1-1;} \mathrm{redox} \mathrm{potential}$ (Eh) in $\mathrm{mV}$, electrical conductivity (EC) in $\mu \mathrm{S}$, temperature (Temp) in ${ }^{\circ} \mathrm{C}, \mathrm{pH}$, dissolved oxygen

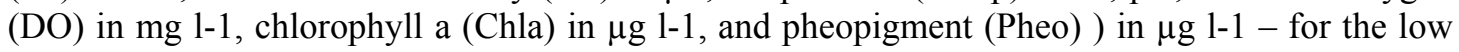
$(\mathrm{n}=10)$, medium $(\mathrm{n}=10)$ and high $(\mathrm{n}=6)$ flow periods at Station 1. (Graph scale of chlorophyll a and pheopigment is tenfold). 
However, as this is a smaller portion of the basin and that alkalinity response may be also derived from the large input of urban sewage and sugarcane plant effluent to the rivers, we could hypothesize that organic matter mineralization has enhanced $\mathrm{pH}$ values by alkalinity generation. In fact, we measured the highest carbon particulate values during the low discharge period, indicating a large amount of organic matter (Figure 7), which after mineralization that may involve $\mathrm{NH}_{4}^{+}$, promotes alkalinity increase (Carmouze, 1994). Since we conversely observed a decrease in $\mathrm{NH}_{4}{ }^{+}$concentration (Figure 6), we can conclude the alkalinity increase may not be associated with organic matter mineralization, but with mineral weathering processes together with liming practices in the sugar cane fields of this river basin.

On the other hand, there was only a slight trend of lower $\mathrm{E}_{\mathrm{H}}$ values at low discharges (Figure 5), and no $\mathrm{E}_{\mathrm{H}}$ correlation with discharge was found. Moreover, $\mathrm{E}_{\mathrm{H}}$ values ranging from 140 to $323 \mathrm{mV}$ indicate that the aquatic environment at this reach of the PSR tended to be oxidant. The lack of temporal variation of $\mathrm{E}_{\mathrm{H}}$ can be related to: $i$. anthropogenic sources with different episodic characteristics (Garádi et al. 1988; Malle, 1996; Pereira and Hostettler, 1993; Ritter, 1988) and ii. The complexity of the groundwater input fluctuations, where oxygen concentrations are regulated by biological processes, interstitial flux, and water residence time (Brunkle and Gonser, 1997; Elsenbeer et al. 1994; Ferrier et al. 1990; Haycock and Burt, 1993; Triska et al. 1993).

Oxygen percentage saturation in the riverine water was generally stable along the three discharge periods (Figure 5). However, $\mathrm{Chl}_{a}$ showed a clear seasonal pattern, with very high values during low flows, resulting in an average low discharge period of $14.88 \mu \mathrm{g} \mathrm{L}^{-1}$. When Pheo mean concentration increased during the medium discharge period, $\mathrm{Chl}_{a}$ decreased. It is possible that during the medium discharge period, the higher dissolved oxygen values were related to the aggregation of both effects - metabolic processes (photosynthesis and respiration) and physical factors (water turbulence in the river channel). However, we cannot ignore the bacteria respiration process consuming $\mathrm{O}_{2}$ and returning $\mathrm{CO}_{2}$ in the water column, which can feed back into the oxygen production by photosynthesis (Summons, 1993; Waichman, 1996).

We recognize that the multiple facets of the measured DO concentrations can make it difficult to identify a temporal pattern of this metric. However, as $\mathrm{E}_{\mathrm{H}}$ was correlated with DO $\left(r_{S}=0,541 ; p<0,01\right)$, we can guess that the sewage and sugarcane industry inputs that take place during the hydrological year seem to be important drivers for $\mathrm{DO}$ and $\mathrm{E}_{\mathrm{H}}$ decrease, notably during low discharge conditions when organic matter inputs can cause a relevant $\mathrm{O}_{2}$ consumption.

Understanding the dynamics of the aquatic environment and biogeochemical processes at this PSR reach can be further amplified when we focus on $\mathrm{Chl}_{a}$, Pheo, DO and Alk. The phytoplankton biomass, as indicated by concentrations of pigments, increased during the low discharge period revealing an increase in photosynthesis activities of the algae communities and subsequent changes in $\mathrm{pH}$, which may have further strengthened the mineral weathering effects by increasing $\mathrm{pH}$ during this low flow period (Margalef, 1986).

As shown in Table 2, which presents the weighted annual means of each studied variable according to the relative frequency of each flow discharge period (low, medium and high) at Station $1(n=26)$ and at stations 2 to $7(n=3)$, the lowest recorded mean annual temperature was found at Station 1, which may reflect the fact that this was the only station that was sampled along the short regional winter.

The main differences between the PSR and the environments of its tributaries are lower $\mathrm{pH}$ and Alk recorded at the PSR stations. This may be a response to differences in their geology and the liming of extensive sugar cane lands. As the tributaries contribute more alkaline waters to the main channel of the basin, the ambiguous decrease of $\mathrm{pH}$ in the PSR 
may be related to the biogeochemical interactions between its fluvial water and the wetlands along its edges and islands, as well as urban and agroindustrial sewage inputs.

It is notable that $\mathrm{Chl}_{\mathrm{a}}$ increased downstream in the PSR even with increasing discharge. In fact, the most important recorded spatial change in the physiochemical characteristics of the studied riverine environment was that the Chlorophyll $a$ increased downstream (Table 2). This fact indicated an increase in phytoplankton biomass in the lower PSR reaches. Anthropogenic point sources cannot be discarded as the drivers of decreased $\mathrm{pH}$ and increased phytoplankton biomass, and both variables can act together as regulators of $\mathrm{C}$ and $\mathrm{N}$ transport in this portion of the basin. Finally, we noted that those tributaries which had the largest lowland areas (Muriaé and Dois Rios rivers) also had the largest chlorophyll values, likely due to a lenthic (slow running) environment during the dry season with large loads of $\mathrm{C}$ and $\mathrm{N}$ into the river waters.

\subsection{Riverine dissolved carbon and nitrogen transport trends}

Also shown in Table 2 are the weighted annual means of each carbon and nitrogen species, as well as their elemental and isotopic ratios, according to the relative frequency of each discharge period (low, medium and high) for the seven sampling stations ( $\mathrm{n}=26$ at Station 1 - PSR/Campos; $n=3$ at the other stations). We can first highlight three patterns for the dissolved components: i) $\mathrm{NO}_{3}{ }^{-}$and DOC in the PSR tended to decrease downstream; ii) The Dois Rios River tended to contribute water with increased concentrations of $\mathrm{NO}_{3}{ }^{-}$to the PSR compared to the other tributaries; and iii) The Muriaé River tended to contribute increased DOC and DON concentrated waters to the PSR compared to the other tributaries.

The decrease in $\mathrm{NO}_{3}{ }^{-}$concentrations in the downstream portion of the PSR can be related not only to instream denitrification processes, but also to sediment nitrate adsorption and phytoplankton uptake. Triska et al. (1989), studying nitrogen dynamics in a small forested catchment in California, USA, measured that $29 \%$ of the nitrate that was added to streamwater was retained in the stream channel, with $10 \%$ in the sediments and $19 \%$ in the microbiota.

The downstream decrease in DOC in the PSR had very little standard deviation at the São Fidélis station, where the DOC was higher than the immediate upstream PSR station. In general, DOC in the rivers tended to decrease downstream due to the heterotrophic organism respiration and autotrophic community intake being converted to particulate organic matter (Hope et al. 1994).

Additionally, the reduced $\mathrm{N}$ species - DON, $\mathrm{NH}_{4}^{+}$and $\mathrm{NO}_{2}^{-}-$concentrations at the PSR/São Fidélis station were larger than at the other PSR stations. The increase in DOC and reduced $\mathrm{N}$ species concentrations indicated that non-point sources from urban sewage as well as the sugarcane agroindustry plants were likely affecting this reach of the PSR. It is common in several Brazilian cities that urban sewage be drained to the river with very little or no treatment, as noted by Costa and Freitas (1989). Figueiredo and Ovalle (1998) found large ammonium and nitrite flux increases in urban streams in the Maricá-Guarapina fluvio-lagunar system, in the same Rio de Janeiro state, related to sewage disposal. Moreover, Calasans et al. (1995), monitoring DOC concentrations in the same reach of the Paraiba do Sul River for 6 months, did not observe seasonal trends in DOC and suggested that, during low flow conditions, increased DOC might be associated with sewage and agriculture sources. Later, Silva et al. (2001) also mentioned that by-products of the alcohol and sugar industries in the PSR basin could potentially reach the river and affect riverine nitrogen concentrations. In the present research, the Muriaé River station contained the largest DOC mean concentration, likely indicating organic matter sources related to the irrigation of the sugarcane fields, which resulted in a mixture of river water and sub-products of the alcohol and sugar industries that is a very rich organic fertilizer called "vinhoto". 
Table 2. Weighted annual means of the studied variables according to the relative frequency of flow periods (low, medium and high) at the seven sampling stations. ( $n=26$ at the PSR/Campos station; $n=3$ at the other stations).

\begin{tabular}{|c|c|c|c|c|c|c|c|c|}
\hline \multicolumn{2}{|c|}{ Variable } & $\begin{array}{c}\text { PSR/ } \\
\text { Itaocara }\end{array}$ & $\begin{array}{c}\text { PSR/ } \\
\text { Cambuci }\end{array}$ & $\begin{array}{c}\text { PSR/ } \\
\text { S.Fidélis }\end{array}$ & $\begin{array}{c}\text { PSR/ } \\
\text { Campos }\end{array}$ & $\begin{array}{c}\text { Pomba } \\
\text { River }\end{array}$ & $\begin{array}{c}\text { Dois Rios } \\
\text { River }\end{array}$ & $\begin{array}{c}\text { Muriaé } \\
\text { River }\end{array}$ \\
\hline $\mathbf{Q}$ & $m 3 \mathrm{~s}^{-1}$ & 710 & 564 & 592 & 872 & 116 & 38 & 87 \\
\hline Temp & ${ }^{\circ} \mathrm{C}$ & 27.7 & 28 & 28.4 & 25.8 & 29.5 & 28 & 27.7 \\
\hline EC & $\mu S$ & 64.0 & 56.9 & 56.3 & 60.3 & 50.3 & 85.8 & 73.4 \\
\hline pH & & 7.54 & 7.53 & 7.42 & 7.46 & 7.81 & 7.8 & 7.6 \\
\hline Eh & $m V$ & 233 & 185 & 215 & 211 & 245 & 210 & 174 \\
\hline OD & $m g l^{-1}$ & 7.93 & 7.53 & 7.97 & 7.95 & 7.68 & 7.80 & 7.37 \\
\hline OD & Sat $\%$ & 101 & 96 & 102 & 97 & 101 & 99 & 94 \\
\hline $\mathrm{Cl}_{\mathrm{a}}$ & $\mu g I^{-1}$ & 1.82 & 5.78 & 4.99 & 8.23 & 1.96 & 4.54 & 6.16 \\
\hline Pheo & $\mu g I^{-1}$ & 0.53 & 0.25 & 0.67 & 0.61 & 0.62 & 0.59 & 0.28 \\
\hline Alk & $\mu E q l^{-1}$ & 368 & 416 & 361 & 363 & 408 & 518 & 478 \\
\hline DIC & $\mu M$ & 390 & 443 & 404 & 396 & 433 & 533 & 512 \\
\hline DOC & $\mu M$ & 309 & 288 & 301 & 232 & 285 & 285 & 329 \\
\hline $\mathbf{T N}$ & $\mu M$ & 70.0 & 59.2 & 65.5 & 55.3 & 38.2 & 61.3 & 39.9 \\
\hline DON & $\mu M$ & 22.9 & 19.3 & 25.1 & 17.8 & 13.7 & 15.4 & 21 \\
\hline $\mathrm{NO}_{3}^{-}-\mathrm{N}$ & $\mu M$ & 44.5 & 37.5 & 35.9 & 35 & 21.8 & 42.7 & 14 \\
\hline $\mathrm{NO}_{2}^{-}-\mathrm{N}$ & $\mu M$ & 0.26 & 0.28 & 0.33 & 0.32 & 0.38 & 0.33 & 0.32 \\
\hline $\mathrm{NH}_{4}^{+}-\mathrm{N}$ & $\mu M$ & 2.4 & 2.1 & 4.2 & 2.2 & 2.3 & 2.9 & 2.2 \\
\hline TSS & $m g l^{-1}$ & 39 & 33 & 64 & 45 & 43 & 43 & 61 \\
\hline CSS & $\%$ & 16 & 9 & 12 & 18 & 13 & 67 & 17 \\
\hline FSS & $\%$ & 84 & 91 & 88 & 82 & 87 & 33 & 83 \\
\hline PC c & $\%$ & 4.29 & 11.5 & 8.18 & 7.68 & 4.89 & 0.99 & 8.03 \\
\hline PC f & $\%$ & 3.27 & 3.5 & 3.93 & 3.61 & 2.4 & 3.46 & 4.04 \\
\hline PC t & $\%$ & 3.41 & 4.24 & 4.24 & 4.34 & 2.65 & 1.72 & 4.04 \\
\hline PN c & $\%$ & 0.39 & 0.84 & 0.77 & 0.53 & 0.27 & 0.07 & 0.32 \\
\hline PN f & $\%$ & 0.56 & 0.4 & 0.46 & 0.41 & 0.29 & 0.38 & 0.43 \\
\hline PN t & $\%$ & 0.53 & 0.44 & 0.5 & 0.43 & 0.28 & 0.17 & 0.42 \\
\hline$(C: N)_{a} c$ & & 13.1 & 16.7 & 15.7 & 19.4 & 22.4 & 16.9 & 25.8 \\
\hline$(C: N)_{a} f$ & & 9.0 & 10.9 & 11.1 & 11.3 & 11.1 & 11 & 10.2 \\
\hline$(C: N)_{a} t$ & & 9.5 & 11.8 & 11.4 & 12.4 & 12.2 & 12.2 & 11.4 \\
\hline$\delta^{13} \mathrm{C} \mathrm{c}$ & $\%$ & -22.27 & -23.13 & -22.07 & -22.41 & -23.23 & -24.17 & -22.86 \\
\hline$\delta^{13} \mathrm{C} \mathrm{f}$ & $\%$ & -22.09 & -22.10 & -21.25 & -21.74 & -21.85 & -22.92 & -21.17 \\
\hline$\delta^{13} \mathrm{C} \mathrm{t}$ & $\%$ & -22.12 & -22.22 & -21.25 & -21.87 & -22.00 & -23.78 & -21.39 \\
\hline
\end{tabular}

As noted previously, the PSR had different physicochemical and limnological characteristics across the three different discharge periods. In considering $\mathrm{C}$ and $\mathrm{N}$ transport for these periods (Figure 6), we found that, relative to the other $\mathrm{C}$ and $\mathrm{N}$ dissolved species, DIC and $\mathrm{NO}_{3}{ }^{-}-\mathrm{N}$ concentrations had their maximum peak values during the low flow period (479 $\mu \mathrm{M}$ and $51.6 \mu \mathrm{M}$, respectively) and minimum values during the high flow period (316 $\mu \mathrm{M}$ and $22.6 \mu \mathrm{M}$, respectively). The Spearman coefficients confirm a significant negative correlation between $\mathrm{NO}_{3}{ }^{-}-\mathrm{N}$ concentration and discharge in the PSR $\left(r_{\mathrm{S}}=-0.668, \mathrm{p}<0.001\right)$, though in the case of DIC, no correlation was found. Positive correlations between discharge and DOC, DON, and $\mathrm{NH}_{4}{ }^{+}-\mathrm{N}$ were significant, with $\mathrm{r}_{\mathrm{S}}$ ranging from 0.505 to $0.687(\mathrm{p}<0.01)$. One interesting result we found is that $\mathrm{NH}_{4}{ }^{+}-\mathrm{N}$ covaried with $\mathrm{C}$ and $\mathrm{N}$ organic species $-\mathrm{DOC}$ 
$\left(\mathrm{r}_{\mathrm{S}}=0.517 ; \mathrm{p}<0.01\right)$ and DON $\left(\mathrm{r}_{\mathrm{S}}=0.415 ; \mathrm{p}<0.04\right)-$, but $\mathrm{NO}_{3}{ }^{-}-\mathrm{N}$ inversely covaried with DOC $\left(\mathrm{r}_{\mathrm{S}}=-0.338 ; \mathrm{p}<0.10\right)$ and DON $\left(\mathrm{r}_{\mathrm{S}}=-0.611 ; \mathrm{p}<0.01\right)$. DIC and DOC also presented a negative correlation between them $\left(\mathrm{r}_{\mathrm{S}}=-0.407 ; \mathrm{p}<0.04\right)$. Therefore, average DIC and $\mathrm{NO}_{3}{ }^{-} \mathrm{N}$ concentrations were larger in the low flow period compared to higher flow periods; conversely, average DOC, DON, and $\mathrm{NH}_{4}{ }^{+}-\mathrm{N}$ concentrations were smaller for the low discharge period (Figure 6).

The small decrease in DIC concentrations during high discharge could be related to a dilution effect, as a background level is maintained by groundwater inputs in response to weathering of soil-rock system (Stumm and Morgan, 1981). Studying 26 Canadian watersheds, Clair et al. (1994) concluded that DIC is driven by geology, not by water inputs from rain events. Additionally, Tipping et al. (1997) observed in UK watersheds that the dissolved and particulate inorganic carbon concentrations were kept homogeneous and high only due to carbonate rocks. However, in the case of the PSR, which is impacted by nutrient inputs, together with high temperatures and alkaline-to-neutral $\mathrm{pH}$ promoting a large phytoplankton biomass, the metabolic processes already discussed can contribute partially to the variation we observed for DIC concentrations.

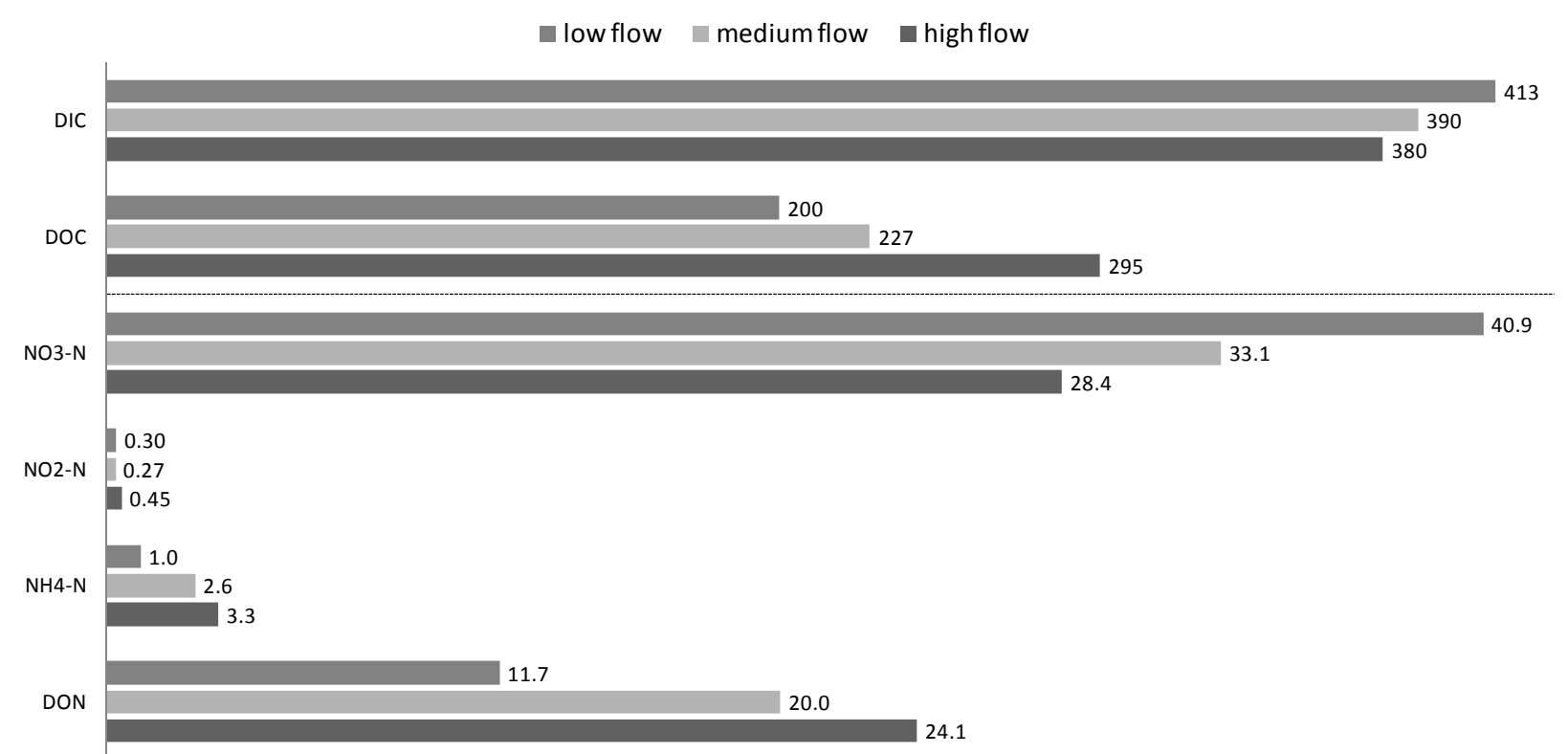

Figure 6. Average concentrations (in $\mu M$ ) of dissolved inorganic carbon (DIC), dissolved organic carbon (DOC), nitrate $\left(\mathrm{NO}_{3}{ }^{-} \mathrm{N}\right)$, nitrite $\left(\mathrm{NO}_{2}{ }^{-} \mathrm{N}\right)$, ammonium $\left(\mathrm{NH}_{4}{ }^{+} \mathrm{N}\right)$ and dissolved organic nitrogen $(\mathrm{DON})$ for the low $(\mathrm{n}=10)$, medium $(\mathrm{n}=10)$ and high $(\mathrm{n}=6)$ flow periods at Station 1 . (Carbon and nitrogen scales are separate for each metric).

Also, the chemistry of groundwater inputs can even reflect the biogeochemical processes that occur in the hyporheic zone that contribute organic compounds and nitrificationdenitrification by-products (Brunke and Gonser, 1997). For instance, a larger nitrate input from wetlands was a consequence of nitrogen remineralization favored by larger oxygen availability during low rainfall season and was observed by Devol et al. (1995) in the Amazon Basin. It is important to stress that in this sector of the PSR, it is rare to find riparian vegetation that could serve as a biogeochemical barrier buffering the nutrient inputs to the river (Correll et al. 1992, Triska et al. 1993). So during low flow conditions DIC increasing can also be related to organic matter mineralization, as the aquatic biota is an important component of the PSR. We found larger suspended particulate matter $\mathrm{C}$ and $\mathrm{N}$ concentrations during this hydrological period of lower flow, (Figure 7) thereby corroborating such an interpretation. 
On the other hand, the alkalinity that originated from mineral weathering, which has a conservative behavior (Devol et al. 1995), would be responsible for background levels, and in the low discharge period also would be the source of inorganic carbon that, together with organic sources, result in the increased $\mathrm{HCO}_{3}{ }^{-}$concentrations we observed (e.g., Carmouze, 1994). These dissolved inorganic species of carbon $\left(\mathrm{HCO}_{3}^{-}\right.$, as well as $\left.\mathrm{CO}_{3}{ }^{2-}\right)$ and nitrogen $\left(\mathrm{NO}_{3}{ }^{-}\right)$are formed by oxidation, while dissolved organic carbon and nitrogen species that decreased during lower discharge, are in reduced form (Mackenzie et al. 1993). This suggests that in the low discharge period, the oxidation processes were more intense than in high discharge period. For dissolved inorganic nitrogen, we observed $\mathrm{NO}_{3}{ }^{-}-\mathrm{N}$ increased while $\mathrm{NO}_{2}{ }^{-}-\mathrm{N}$ and $\mathrm{NH}_{4}{ }^{+}-\mathrm{N}$ decreased in the low flow conditions. This indicates that high nitrification rates were probably due to respiration activity of nitrifying bacteria that would also favor the observed DIC increase.

Nitrogen fertilizers and "vinhoto" are applied to the soils of the sugar cane fields of the region in a time of the year that coincides with the low river flow period. These fertilizer inputs of organic and inorganic nitrogen are quickly transported off the land in runoff and through soil water and groundwater, ultimately ending up in the river water. Keeney (1987) reported an increase in nitrate groundwater due to fertilization and irrigation, typical practices in the sugar cane fields of the lower portion of the PSR Basin. Several other studies also associated this agricultural management practice to nitrate increase in fresh waters (Bauder et al. 1993).

Triska et al. (1989) noted the occurrence of nitrification processes such as DON and N$\mathrm{NH}_{4}{ }^{+}$from hyporheic groundwater reach more aerobic conditions in the fluvial channel. This can be one of the reasons that nitrate concentrations increased in the river and can overweight the important denitrification rates that occurred in the wetland along the edge of the lower portion of the Paraiba do Sul River. This behavior was observed by Seitzinger (1994) studying organic matter mineralization and denitrification in riparian zones. Also, irrigation in agriculture lands can increase denitrification rates, as observed by Lowrance (1992), leading to other mitigating processes affected increased nitrate concentrations.

In the present study we observed a seasonal pattern in which DOC concentrations decreased with decreased discharge. Thus, a measured episodic high DOC concentration in July during the low discharge period could be attributed to the cited anthropogenic sources. Watershed studies in northern England (Tipping et al. 1997) also related non-point sources inputs (industrial effluents) to DOC increase in low river flow conditions.

As a matter of fact, Hope et al. (1994) observed relationships between increased discharge and increased DOC concentrations, but these were not always statistically significant. For the present study, we observed a positive correlation between DOC and discharge $\left(\mathrm{r}_{\mathrm{s}}=0.5051 ; \mathrm{p}=0.0085 ; \mathrm{n}=26\right)$. The increased $\mathrm{pH}$ from sugarcane crop lands due to liming increased the solubility of the soil organic compounds, thereby increasing DOC leaching and subsequent inputs to the streams and rivers.

Two dissolved $\mathrm{N}$ species also had strong positive correlations between their concentrations and discharge $(n=26)$ : DON $\left(r_{s}=0.6328 ; p=0.0005\right)$; and $\mathrm{NH}_{4}{ }^{+}\left(r_{s}=0.6868\right.$; $\mathrm{p}=0.0001)$. These positive relations also were found in watersheds of the Sepetiba Bay, in the state of Rio de Janeiro (Rezende, 1993). These facts suggest the influence of lateral and subsuperficial fluxes from hyporheic zone, as well as insular soils, also proposed by Hedges et al. (1994) for Amazonian rivers enriching fluvial waters with $\mathrm{C}$ and $\mathrm{N}$ dissolved reduced forms.

On the other hand, $\mathrm{NO}_{3}{ }^{-}$concentrations decreased with increasing discharge in the PSR $\left(r_{s}=-0.66815 ; p=0.0002\right)$. This negative correlation corroborates the hypothesis that reductive reactions are predominant in the biogeochemical processes in the basin, and that denitrification rates were large in the wetlands along the edges of the river and in the islands. 
If not the increase of N-reduced species, we also could guess that decreased nitrate would be related only due to the dilution factor during high waters.

\subsection{Riverine particulate carbon and nitrogen transport trends}

At Station 1, the average TSS (total solid suspended) was equal to $45 \mathrm{mg} \mathrm{l}^{-1}$ (SD $=40 \mathrm{mg}$ $\left.1^{-1}\right)$. The fine suspended solid (FSS) fraction accounted for the larger portion of the total solids $(82 \%)$, while the coarse suspended solid (CSS) fraction accounted for $18 \%$. TSS seasonal variation was very wide (10 to $\left.153 \mathrm{mg} \mathrm{l}^{-1}\right)$, with TSS and discharge strongly correlated $\left(\mathrm{r}_{\mathrm{S}}=0.907 ; \mathrm{p}<0.01\right)$. As a general evaluation of the transported particulate matter in this basin, we noted that TSS along the PSR was larger at Station 3 (São Fidélis city), while the Muriaé River had the highest values among the tributaries (Table 2). The increase of TSS at the stations of São Fidélis and Campos could be a response to sand mining that we observed along the river channel edges at this reach, as well as floating sugarcane detritus observed in the PSR and the Muriaé River waters. Besides these anthropogenic factors, such TSS increases could occasionally occur as a response to sediment erosion from deforested riparian zones and from insular soils during extreme high discharge events.

As seen in Figure 7, all organic $\mathrm{C}$ and $\mathrm{N}$ in suspended solid fractions had the same seasonal variability: higher concentrations in the low flow period and decreasing concentrations in the medium flow period, reaching the lowest values in the high flow period. This inverse correlation between discharge and particulate organic $\mathrm{C}$ and $\mathrm{N}$ concentration was significantly stronger for fine solid fractions - FPOC $\left(\mathrm{r}_{\mathrm{S}}=0.948 ; \mathrm{p}<0.01\right)$ and FPON $\left(\mathrm{r}_{\mathrm{S}}=\right.$ $0.944 ; \mathrm{p}<0.01)$.

In all suspended solid sediment fractions - TSS, CSS and FSS - we observed clear seasonal patterns regarding $\mathrm{C}$ and $\mathrm{N}$ atomic ratios, as well as isotopic $\mathrm{C}$ composition. The highest $\delta^{13} \mathrm{C}$ values (less negative values) were observed during the low flow, with the exception when the highest CSS $\delta^{13} \mathrm{C}$ occurred in the medium flow period. Inverse to $\delta^{13} \mathrm{C}$, $(\mathrm{C}: \mathrm{N})_{a}$ values tended to be smaller during the low flow period and larger during the high and medium flow periods for all sediment fractions. The inverse relation between $(\mathrm{C}: \mathrm{N})_{a}$ and $\delta^{13} \mathrm{C}$ values was more significant for FSS and TSS $\left(r_{S}=-0.864 ; p<0.01\right.$ and $r_{S}=-0.772 ; p<0.01$, respectively) than for CSS ( $\left.\mathrm{r}_{\mathrm{S}}=-0.439 ; \mathrm{p}<0.025\right)$.

Larger $\mathrm{C}$ and $\mathrm{N}$ concentrations in the suspended particulate matter suggested an important phytoplankton role in the associated biogeochemical processes (Tipping et al. 1997). It also could be expected that in the beginning of sugar cane harvest, when burning was used, the organic matter entered the river through the draining and irrigation channels built in the farms lands. Hope et al. (1994), in a review manuscript, described that, as a consequence of burning, followed by drought, as we observed in the studied watershed, there was an increase in superficial soil erosion, promoting larger carbon inputs to rivers. In another study, it was observed in Scottish rivers during low flow conditions that increased particulate carbon in river water was correlated with till in agriculture lands (Hope et al. 1997), a trend that also was found in the lower portion of the Paraiba do Sul.

The lower $(\mathrm{C}: \mathrm{N}) a$ ratios in the PSR during low discharge conditions depict a phytoplankton role in increased $\mathrm{C}$ and $\mathrm{N}$ concentrations in the suspended sediment. Hudon et al. (1996), studying the Great Whale River in Canada, observed an even stronger relationship between phytoplankton and increased carbon concentration in fine suspended particulate. Moreover, Meade (1985), in the Amazon Basin, observed over three years of monitoring that fine suspended particulates were more important in low discharge conditions, making the presence of phytoplankton an important component in the transported riverine particulate $\mathrm{C}$ and $\mathrm{N}$. 
FIGUEIREDO, R. de O.; OVALLE, A. R. C.; REZENDE, C. E. de.; MARTINELLI, L. A. Carbon and Nitrogen in the Lower Basin of the Paraíba do Sul River, Southeastern Brazil: Element fluxes and biogeochemical processes. Ambi-Agua, Taubaté, v. 6, n. 2, p. 7-37, 2011. (doi:10.4136/ambi-agua.183)

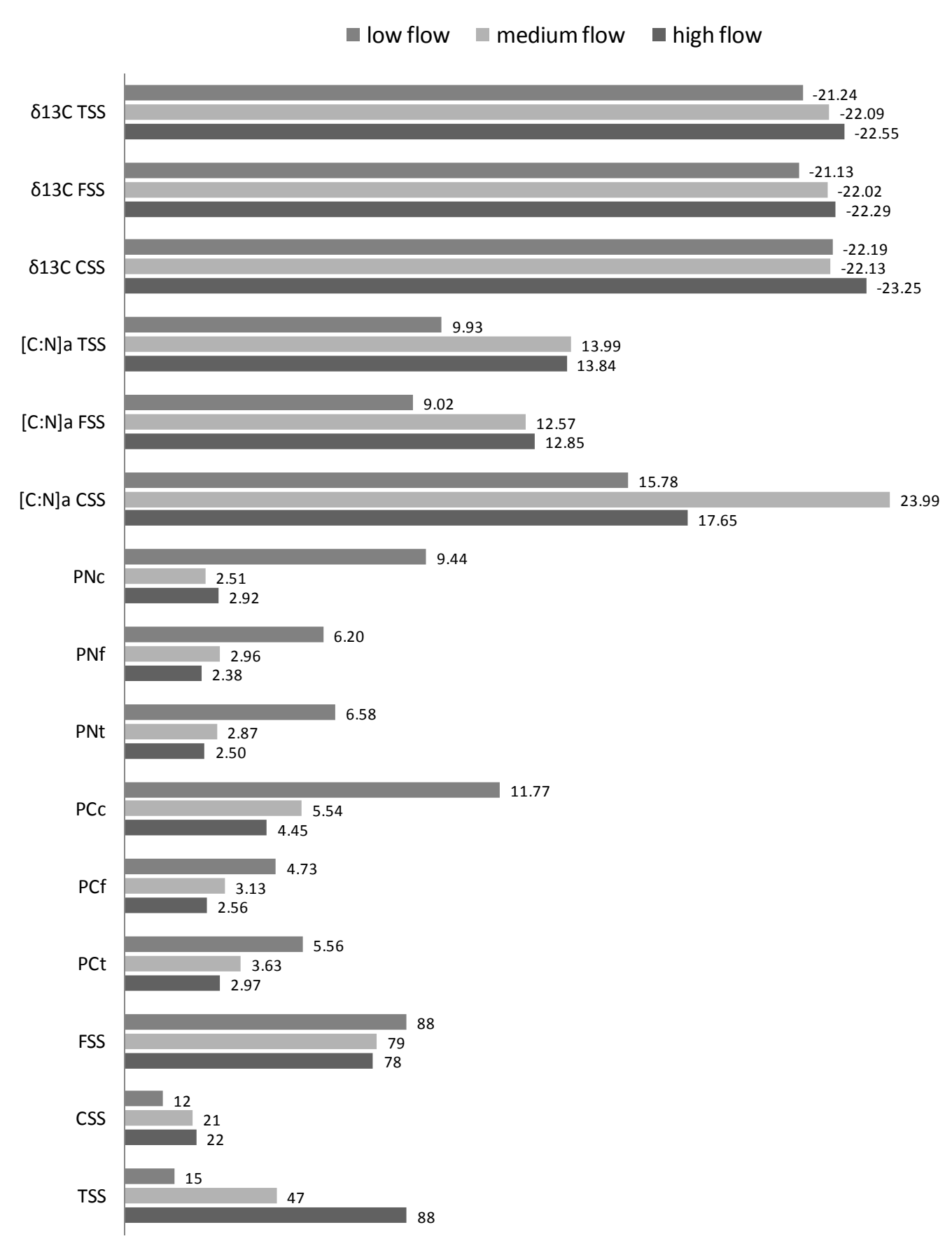

Figure 7. Total suspended sediment (TSS) means (in $\mathrm{mg} \mathrm{l}^{-1}$ ), percent of each particulate fraction $($ coarse $=$ CSS, and fine $=$ FSS), mean concentrations (in \%) of particulate carbon (PC) and nitrogen $(\mathrm{PN})$, mean values of isotopic carbon composition, and mean carbon and nitrogen atomic ratios in each fraction of the particulate material in the low $(n=10)$, medium $(n=10)$ and high $(n=6)$ flow periods at Station 1.

Effluents from sugar and ethanol plants into the PSR waters should not be forgotten as organic matter sources (Ali and Soltan, 1996). Such input would increase riverine organic particulate matter in the low discharge period, which coincided with the most intense production time of these agro-industrial plants in the region. During low flows, the aquatic macrophytes of the riparian zones and the islands along the lower portion of the PSR may be retaining part of the sediments transported by the river. Svendsen and Kronvang (1993), in watersheds studies in Denmark, observed such dynamics during low flow conditions, when a 
slower current velocity favored adsorption processes in sediments and larger nutrient uptake by the aquatic biota communities. In the PSR basin, these processes could be buffering hydrochemical responses to the diversity of inputs from anthropogenic sources. In a study in Tennessee, USA, Mulholland and Hill (1997) suggested that biogeochemical processes related to phytoplankton and sediment adsorption reactions were more important during low discharges, attenuating riverine nutrient concentrations. If these processes were not important in the PSR, $\mathrm{C}$ and $\mathrm{N}$ concentrations would be even higher during low flow conditions.

However during the high discharge period TSS fluxes accounted for about $50 \%$ of the annual TSS fluxes. These TSS high period fluxes, added together with the TSS during the medium discharge period $\left(\mathrm{Q}=600-1200 \mathrm{~m}^{3} \cdot \mathrm{s}^{-1}\right)$, accounted for $91 \%$ of the annual flux of TSS. High erosion potential is likely the reason for higher TSS values during the high and medium discharge periods (Figure 7). Importantly, measurement of increased coarse particulates during higher flow periods is affected by the fact that this fraction is generally transported along deeper river waters (Meade, 1985).

As Hope et al. (1994) have pointed out, higher discharge events are very important in promoting pulses of $\mathrm{C}$ and $\mathrm{N}$ transport in watersheds; often, the absence of such data (i.e., capturing higher discharge events) is a major a reason that $\mathrm{C}$ and $\mathrm{N}$ are underestimated in mass flux calculations in many studies. In the present study, we observed that 10 days $(2.7 \%$ of the year) of the highest daily discharges were responsible for $10 \%$ of the particulate $\mathrm{C}$ and $\mathrm{N}$. These results are due to the biogeochemical dynamics during the rainy season, when surface and sub-surface runoff is proportionally higher than groundwater input (Rees et al. 1989). Heavy rain and large discharge promote larger TSS in the river water as a consequence of larger soil erosion rates, bed sediment suspension, and aloctone material transported from the riverine edges and islands along this low reach of the PSR.

On the other hand, $\mathrm{C}$ and $\mathrm{N}$ concentrations tended to decrease in all TSS fractions (Figure 7), which seemed to be related to the phytoplankton biomass decrease and to smaller agro-industry effluents inputs during this time. The $(\mathrm{C}: \mathrm{N}) a$ ratio increase in medium and high discharge periods corroborated this hypothesis as phytoplankton and agro-industry effluents are richer in N (Bianchi et al. 1997; Hudon et al. 1996) than eroded soils which are generally N poor (Bramley et al. 1996; McDowell and Asbury, 1994).

\subsection{Carbon and nitrogen sources for transported organic matter.}

For our soil samples, the highest $\mathrm{C}$ and $\mathrm{N}$ concentrations were found in the fine fraction, except for one sample location (SO-2), which corresponded to a wetland with pastures located about $30 \mathrm{~km}$ downstream of São Fidélis (Table 3 and Figure 3). Sample bed sediment, named as $\mathrm{K}$, is from a site immediately downstream of an agro-industrial plant. Fine fractions of the $\mathrm{K}$ sample had the highest $\mathrm{C}$ concentration, $(\mathrm{C}: \mathrm{N})_{a}$ and ${ }^{813} \mathrm{C}$ compared to all collected samples. Unfortunately, we do not have chemical data of $\mathrm{K}$ coarse sample. The $\mathrm{C}_{3}$ macrophyte species (MA1) had higher $(\mathrm{C}: \mathrm{N})_{a}$ and $\mathrm{C}$ and $\mathrm{N}$ concentrations than bed sediments and soils samples. On the other hand, MA1 had the smallest ${ }^{\delta 13} \mathrm{C}(-28.19 \%$ \% $)$.

We were able to trace the sources of the transported organic $\mathrm{C}$ and $\mathrm{N}$ by comparing the $(\mathrm{C}: \mathrm{N})_{a}$ and ${ }^{\delta 13} \mathrm{C}$ values of the main organic matter sources to the $(\mathrm{C}: \mathrm{N})_{a}$ and ${ }^{\delta 13} \mathrm{C}$ values measured for the suspended and bed sediment. The data used to generate this analysis included results from our sampling procedure for soils and macrophytes (Table 3) as well as data from Calasans (1998), who conducted a study in a small watershed nearby Campos dos Goytacazes city. These organic matter sources were:

- Riparian soils identified as SO-2, SO-3 and SO-4 (Table 3).

- Insular flooded soils identified as SO-1 (Table 3). 
FIGUEIREDO, R. de O.; OVALLE, A. R. C.; REZENDE, C. E. de.; MARTINELLI, L. A. Carbon and Nitrogen in the Lower Basin of the Paraíba do Sul River, Southeastern Brazil: Element fluxes and biogeochemical processes. Ambi-Agua, Taubaté, v. 6, n. 2, p. 7-37, 2011. (doi:10.4136/ambi-agua.183)

- Aquatic macrophyte (unidentified species of $\mathrm{C}_{3}$ plant) sampled near to $\mathrm{J} 3$ point and identified as MA1 (Table 3).

- Aquatic macrophytes (six species: Eichhornia azurea, Eichhornia crassipes, Salvinia sp., Trapa natans, Utricularia sp., and Nymphoides humbolditianum) (Calasans, 1998)

- Phytoplankton (Calasans, 1998)

- Sugarcane plant (six different varieties) (Calasans, 1998)

- Pasture grass (Brachiaria sp.) (Calasans, 1998)

- Byproducts from sugarcane agroindustry (Calasans, 1998)

- Leaves from Atlantic Forest litterfall (Calasans, 1998)

- Branches from Atlantic Forest litterfall (Calasans, 1998)

Table 3. Carbon and nitrogen concentrations (\%), elemental $(\mathrm{C}: \mathrm{N})_{a}$ and isotopic composition ${ }^{\delta 13} \mathrm{C}$ $(\%$ ) in bed sediments (A to X), soils (SO-1 to SO-4), and macrophytes (MA1) samples in fine $(\varnothing<63 \mu \mathrm{m})$ and coarse $(\varnothing<63 \mu \mathrm{m})$ fractions.

\begin{tabular}{|c|c|c|c|c|c|c|c|c|}
\hline Sample & $\begin{array}{c}\mathbf{C} \\
\varnothing<63 \mu \mathrm{m}\end{array}$ & $\begin{array}{c}\mathbf{N} \\
\varnothing<63 \mu \mathrm{m}\end{array}$ & $\begin{array}{c}\mathbf{C} \\
\varnothing>63 \mu \mathrm{m}\end{array}$ & $\begin{array}{c}\mathbf{N} \\
\varnothing>63 \mu \mathrm{m}\end{array}$ & $\begin{array}{c}(\mathbf{C}: \mathbf{N}) \mathbf{a} \\
\varnothing<63 \mu \mathrm{m}\end{array}$ & $\begin{array}{c}(\mathbf{C}: \mathbf{N}) \mathbf{a} \\
\varnothing>63 \mu \mathrm{m}\end{array}$ & $\begin{array}{c}\boldsymbol{\delta}_{13} \mathbf{C} \\
\varnothing<63 \mu \mathrm{m}\end{array}$ & $\begin{array}{c}\boldsymbol{\delta}_{13} \mathbf{C} \\
\varnothing>63 \mu \mathrm{m} \\
\end{array}$ \\
\hline A & 2.52 & 0.05 & 0.40 & $<0.05$ & 58.6 & & -22.40 & -23.59 \\
\hline B & 2.65 & 0.24 & 0.50 & $<0.05$ & 12.8 & & -20.24 & -20.64 \\
\hline $\mathrm{C}$ & 3.32 & 0.31 & 0.20 & $<0.05$ & 12.5 & & -20.33 & -21.37 \\
\hline D & 2.84 & 0.21 & 0.66 & $<0.05$ & 15.7 & & -21.27 & -22.97 \\
\hline E & 2.31 & 0.12 & 1.47 & 0.08 & 22.4 & 21.4 & -22.44 & -23.35 \\
\hline $\mathrm{F}$ & 2.58 & 0.21 & 2.20 & 0.14 & 14.3 & 18.3 & -20.01 & -20.06 \\
\hline G & 2.72 & 0.20 & 0.13 & $<0.05$ & 15.8 & & -20.03 & -21.16 \\
\hline $\mathrm{H}$ & 1.68 & 0.12 & 0.31 & 0.09 & 16.3 & 4.0 & -20.63 & -21.53 \\
\hline I & 2.71 & 0.20 & 0.20 & $<0.05$ & 15.8 & & -19.70 & -19.58 \\
\hline $\mathrm{J} 1$ & 1.97 & 0.13 & 2.17 & 0.16 & 17.6 & 15.8 & -23.07 & -23.18 \\
\hline $\mathrm{J} 2$ & 2.07 & 0.09 & 1.37 & 0.09 & 26.7 & 17.7 & -22.82 & -23.89 \\
\hline $\mathrm{J} 3$ & 3.30 & 0.28 & 1.31 & 0.10 & 13.7 & 15.2 & -19.01 & -18.65 \\
\hline $\mathrm{K}$ & 4.80 & 0.09 & & & 62.0 & & -16.20 & ndt \\
\hline $\mathrm{L}$ & 2.88 & 0.10 & 0.83 & $<0.05$ & 33.5 & & -19.50 & -17.34 \\
\hline M & 2.53 & 0.14 & 0.49 & $<0.05$ & 21.0 & & -22.57 & -22.45 \\
\hline $\mathrm{N}$ & 2.45 & 0.14 & 1.01 & 0.07 & 20.3 & 16.8 & -22.87 & -22.91 \\
\hline $\mathrm{O}$ & 2.38 & 0.12 & 1.89 & 0.11 & 23.1 & 20.0 & -20.40 & -20.69 \\
\hline $\mathrm{P}$ & 2.90 & 0.13 & 3.24 & 0.20 & 25.9 & 18.8 & -16.92 & -16.96 \\
\hline Q & 1.91 & 0.07 & 1.27 & $<0.05$ & 31.7 & & -23.16 & -22.82 \\
\hline $\mathrm{R}$ & 2.70 & 0.14 & 5.52 & 0.24 & 22.4 & 26.7 & -20.03 & -26.02 \\
\hline $\mathrm{S}$ & 2.39 & 0.11 & 2.03 & 0.09 & 25.3 & 26.2 & -23.11 & -24.56 \\
\hline $\mathrm{T}$ & 2.14 & 0.11 & 3.10 & 0.18 & 22.6 & 20.0 & -22.72 & -23.20 \\
\hline $\mathrm{U}$ & 1.44 & $<0.02$ & 0.27 & $<0.05$ & & & -21.60 & -22.38 \\
\hline V & 1.84 & 0.12 & 0.22 & $<0.05$ & 17.8 & & -20.53 & -20.57 \\
\hline $\mathrm{X}$ & 3.14 & 0.20 & 0.13 & $<0.05$ & 18.3 & & -20.68 & -20.80 \\
\hline SO-1 & 4.03 & 0.28 & 0.66 & $<0.05$ & 16.7 & & -18.55 & -19.17 \\
\hline SO-2 & 2.20 & 0.13 & 2.59 & 0.20 & 19.7 & 15.1 & -22.58 & -22.41 \\
\hline $\mathrm{SO}-3$ & 2.14 & 0.11 & 1.39 & 0.11 & 22.6 & 14.7 & -22.66 & -22.80 \\
\hline $\mathrm{SO}-4$ & 1.82 & 0.10 & 0.88 & 0.05 & 21.2 & 20.5 & -23.31 & -24.42 \\
\hline MA1 & \multicolumn{2}{|c|}{$\mathrm{C}=36.2 \%$} & \multicolumn{2}{|c|}{$\mathrm{N}=1.40 \%$} & \multicolumn{2}{|c|}{$(\mathrm{C}: \mathrm{N}) \mathrm{a}=\mathbf{3 0 . 3}$} & \multicolumn{2}{|c|}{$\delta_{13} \mathrm{C}=-28.19 \%$} \\
\hline
\end{tabular}


Most of the evaluation of $\mathrm{C}$ and $\mathrm{N}$ sources to the PSR is based on plotting $(\mathrm{C}: \mathrm{N})_{a}$ against $\delta^{13} \mathrm{C}$ of the listed sources, and is shown in Figure 8. Forest litterfall, together with aquatic macrophytes, is plotted in the lower left side of the graph, while sugarcane and its byproducts, together with grass, are plotted in the upper right side. Phytoplankton is located in the low center of the graph, close to riparian and insular soils, except the coarse fraction of insular soils, which is poorer in $\mathrm{N}$.

The seasonal variation of $(\mathrm{C}: \mathrm{N}) a$ and $\delta^{13} \mathrm{C}$ in the suspended sediment (Figure 7) is likely driven by the fact that during low discharge, this material is enriched in nitrogen ([C:N]a= 9.93) and its isotopic composition is heavier $\left(\delta^{13} \mathrm{C}=-21.24 \%\right.$ ). This is an indication that the main source of this material in the dry season is the phytoplankton biomass, which is richer in $\mathrm{N}$ and isotopically heavier than other sources, such as macrophytes and forest litterfall (Figure 8 ) that are mainly transported into the streams and rivers during the raining season (Hope et al. 1994) but retained in soils in the dry season (Hedges, 1992). As observed in Figures 8 and 9, TSS (C:N) $a$ and $\delta^{13} \mathrm{C}$ were closer to macrophytes and forest litterfall values during periods of higher discharges.

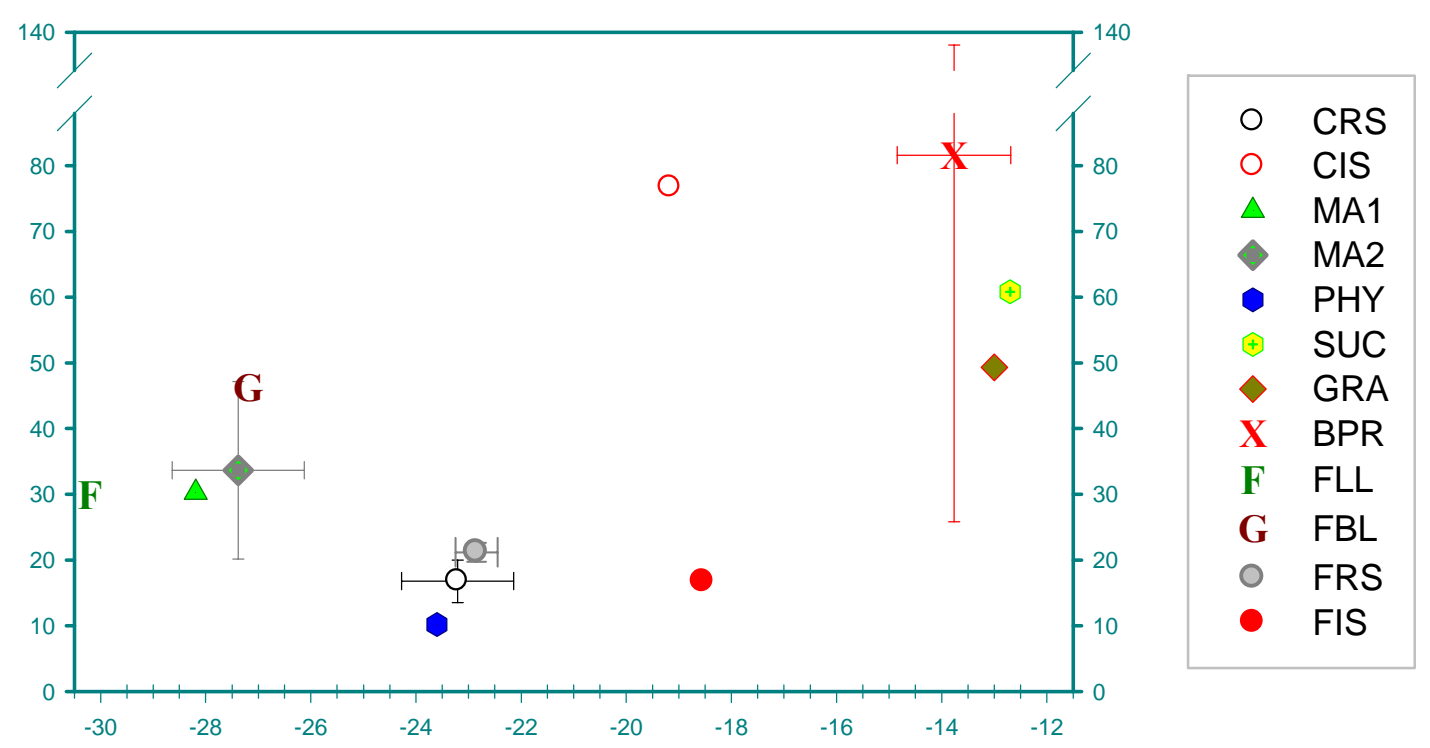

Figure 8. Elemental and isotopic composition of the potential sources of $\mathrm{C}$ and $\mathrm{N}$.

where: CRS is the coarse fraction of riparian soils;

CIS is the coarse fraction of insular soils;

MA1 is the aquatic macrophyte species sampled near the $\mathrm{J} 3$ point ;

MA2 is another group of aquatic macrophytes (6 species: Eichhornia azurea, Eichhornia crassipes, Salvinia sp., Trapa natans, Utricularia sp., and Nymphoides humbolditianum) (Calasans, 1998);

PHY is the phytoplankton (Calasans, 1998);

SUC is sugarcane plants (6 different varieties) (Calasans, 1998);

GRA is pasture grass (Brachiaria sp.) (Calasans, 1998);

BPR is the byproducts from sugarcane agroindustry (Calasans, 1998);

FLL is the leaves of the Atlantic Forest litterfall (Calasans, 1998);

FBL is the branches of the Atlantic Forest litterfall (Calasans, 1998);

FRS is the fine fraction of riparian soils;

FIS is the fine fraction of insular soils.

For the riparian soils we observed a large difference in $(\mathrm{C}: \mathrm{N}) a$ ratios between the soils fractions, but no difference for $\delta^{13} \mathrm{C}$. This suggests that $\delta^{13} \mathrm{C}$ is a better source indicator than $(\mathrm{C}: \mathrm{N}) a$ and can be explained by the quick organic matter decomposition in the coarse fraction of these flooded soils, mainly composed by plant detritus, thereby quickly liberating nitrogen 
and promoting higher $(\mathrm{C}: \mathrm{N}) a$ values. Other likely potential sources in which riparian and insular fine soil fractions and $\delta^{13} \mathrm{C}$ reflected a mix of terrestrial and aquatic sources include phytoplankton (during low discharge) as well as pastures grass and sugarcane fields, which were the predominant vegetation cover in this lower portion of the PSR. An important $\mathrm{C}$ and $\mathrm{N}$ source that was not characterized are urban areas, but it is known that element and isotopic compositions are very variable in these areas, largely due to the characteristics of local human communities, such as dietary and domestic products (Billen, 1993).

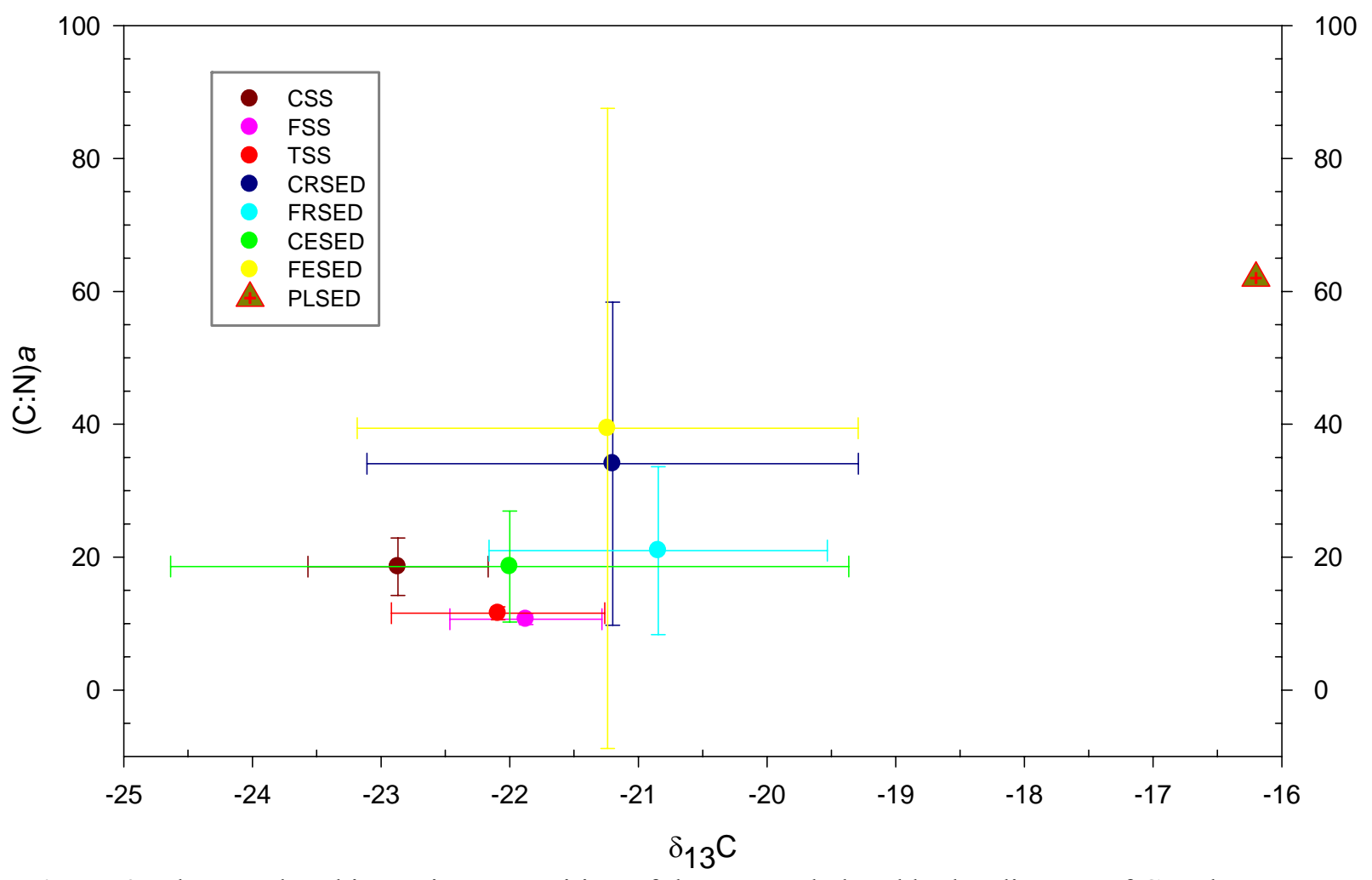

Figure 9. Elemental and isotopic composition of the suspended and bed sediments of $\mathrm{C}$ and $\mathrm{N}$.

where: CSS is the coarse fraction of the suspended sediment;

FSS is the fine fraction of the suspended sediment;

TSS is the total suspended sediment;

CRSED is the coarse fraction of the river sediment;

FRSED is the fine fraction of the river sediment;

CESED is the coarse fraction of the estuary sediment;

FESED is the fine fraction of the estuary sediment;

PLSED is the bed sediment under agroindustry effluent effects

Observation of the spatial variation of $(\mathrm{C}: \mathrm{N}) a$ and $\delta^{13} \mathrm{C}$ in the suspended sediment along the seven stations (Table 2) indicates some clues of $\mathrm{C}$ and $\mathrm{N}$ sources; in the Dois Rios River, $\delta^{13} \mathrm{C}$ is lighter, suggesting litterfall as the main source, as it is the closest sampling station to headwater forests. On the other hand, heavier $\delta^{13} \mathrm{C}$ values in the Pomba and Muriaé rivers indicated soil degradation, as Trumbore et al. (1995) have associated for pastures in the north region of Brazil.

Along the Paraíba do Sul River, we observed that samples from Station 1, despite being richer in phytoplankton than the other three stations in the main channel of the basin, had the highest (C:N) $a$ in the suspended sediment. This fact can be explained by other rich $\mathrm{C}$ sources, including urban sewage and the byproducts of the sugarcane agroindustry increasing $(\mathrm{C}: \mathrm{N}) a$. We observed that bed sediment tended to be poorer in nitrogen than suspended sediment (Figure 9), likely due to the presence of phytoplankton in the FSS as well as to the loss of N 
by biota $\mathrm{N}$ uptake, denitrification and other biogeochemical processes as the particulate matter sank and is deposited along the channel bottom. The isotopic signature of the FSS (Figures 8 and 9) seemed to have not only phytoplankton as an important source, but also riparian soils. However lower $\delta^{13} \mathrm{C}$ values in the CSS indicated a greater effect of forest litterfall and aquatic macrophytes in such sediment fraction. For bed sediment, we observed heavier $\delta^{13} \mathrm{C}$, which suggested important anthropogenic sources affecting this riverine component, as it is was similar to SUC and BPR as well as GRA. Adversely, bed sediment $\delta^{13} \mathrm{C}$ is different from riparian soils $\delta^{13} \mathrm{C}$.

Moreover, $\delta^{13} \mathrm{C}$ insular soils are higher than the suspended sediments and the bed sediments (Figure 8), which suggest a relevant contribution of organic matter sources from pasture as well as from sugarcane fields to these insular soils, due to typical flooding events in the wet season. In this case, the distance from the islands to the headwaters of the basin, plus the isolation promoted by the river channel to the mentioned sources, would promote an isotopic signature of the insular soils different from the signatures the forest litterfall sources. In addition, we could not detect effects of aquatic macrophytes in the insular soils. As a consequence, we can suggest that the insular soil erosion and the subsequent resuspension along the channel may not be as important to the suspended sediment composition as riparian soils seem to be. Thus, these islands may play the role of deposition sites during flooding instead of potential export sources.

As expected, the bed sediments close to the sugarcane agroindustry plant showed $\delta^{13} \mathrm{C}$ values affected by such activity (Figures 8 and 9 ). The bed sediment in a reach of the PSR that has in one of its edge an agroindustry plant had a $\delta^{13} \mathrm{C}$ fine fraction equal to $-16.20 \%$ (Table 3). After $1.5 \mathrm{~km}$ downstream, the $\delta^{13} \mathrm{C}$ fine fraction substantially decreased to $19,50 \%$, but after an additional $4 \mathrm{~km}$ downstream, this anthropogenic signal disappeared $\left(\delta^{13} \mathrm{C}=-22.57^{0} \%\right.$ ), returning to a level of $\delta^{13} \mathrm{C}$ inside the standard deviation of the PSR bed sediment $\delta^{13} \mathrm{C}$ data range. Unfortunately, the coarse bed sediment sample collected near the agroindustrial unit was lost, but in the sample point just $1.5 \mathrm{~km}$ downstream, the $\delta^{13} \mathrm{C}$ coarse fraction was anomalous $(-17.34 \%$ ) indicating the important effects of sugarcane production sources. After $4 \mathrm{~km}$ downstream, we also observed this anthropogenic signal disappear $\left(\delta^{13} \mathrm{C}\right.$ $=-22.45^{\circ} \% 0$ ) in the coarse fraction.

Finally, we observed a wide $\delta^{13} \mathrm{C}$ range for the estuarine bed sediments, especially in the coarse fraction (CESED) (Figure 9). Considering the results by Lacerda et al. (1986) for $\delta^{13} \mathrm{C}$ of mangrove vegetation (from -25.15 to $-27.60 \%$ ) , of marine suspended sediment (mean $=$ $20.50 \%$ ), and of marine algae (from -17.28 e $-18.34 \%$ ), it seems that CESED has been affected by all these sources of carbon. On the other hand, the FESED $\delta^{13} \mathrm{C}$ suggested a minor role of the mangrove to these estuarine sediments fraction.

\subsection{Carbon and nitrogen loads to the ocean}

The total carbon output to the ocean was $260,000 \mathrm{Mg}$ year $^{-1}$, corresponding, in terms of drainage basin, to a flux of 4,640 kg km year $^{-1}$ (Table 4). On the other hand the $26,000 \mathrm{Mg}$ year ${ }^{-1}$ total nitrogen output was ten times smaller than carbon output and corresponded, in terms of drainage area, to $370 \mathrm{~kg} \mathrm{~N} \mathrm{~km}^{-2}$ year $^{-1}$. The fine suspended particulate carbon dominated mass transport with fluxes three fold larger than $\mathrm{C}$ in the coarse particulate fraction. The same trend occurred for organic nitrogen particulate fluxes, as fine fraction accounts for more than $80 \%$ of the total organic nitrogen particulate transport.

The PSR Basin load to the Atlantic Ocean was estimated at $27 \mathrm{~km}^{3}$ year $^{-1}$ (Table 5). Regarding dissolved elements fluxes, DIC mass flux clearly prevailed to DOC accounting for more than $60 \%$ of the total dissolved carbon fluxes (Table 4). As can be observed at Table 5 dissolved nitrogen flux was dominated by dissolved inorganic nitrogen (DIN), mainly as 
nitrate (as seen at Table 4), while annual dissolved organic nitrogen (DON) flux accounted for almost half of the dissolved inorganic nitrogen mass transport $\left(\sim 240 \mathrm{~kg} \mathrm{~km}^{-2}\right.$ year $\left.^{-1}\right)$.

Table 4. Elements output mass fluxes of the Paraíba do Sul River Basin for the studied period.

(TSS is total suspended sediments, PCt is total of particulate carbon, PCf is fine particulate carbon, PCc is coarse particulate carbon, DIC is dissolved inorganic carbon, DOC is dissolved organic carbon, TC is the total carbon in the particulate and dissolved material, PNt is total of particulate nitrogen, $P N f$ is fine particulate nitrogen, $\mathrm{PNC}$ is coarse particulate nitrogen, $\mathrm{NO}_{3}{ }^{-} \mathrm{N}$ is nitrogen as nitrate, $\mathrm{NO}_{2}^{-}-\mathrm{N}$ is nitrogen as nitrite, $\mathrm{NH}_{4}^{+}-\mathrm{N}$ is nitrogen as ammonium, DON is dissolved organic nitrogen, and $T N$ is total nitrogen in the particulate and dissolved material.).

\begin{tabular}{|c|c|c|c|c|}
\hline & $\underset{\text { Mg day }^{-1}}{\text { Minimum }}$ & $\underset{\text { Mg day }^{-1}}{\text { Maximum }}$ & $\begin{array}{c}\text { Annual } \\
\text { Mg year }^{-1}\end{array}$ & $\begin{array}{c}\text { Annual } \\
\mathrm{kg} \mathrm{km}^{-2} \text { year }^{-1}\end{array}$ \\
\hline TSS & 380 & 25,000 & $1,600,000$ & 28,000 \\
\hline $\mathrm{PCt}$ & 24 & 820 & 48,000 & 840 \\
\hline $\mathrm{PCf}$ & 19 & 500 & 36,000 & 630 \\
\hline PCc & 5.0 & 320 & 12,000 & 210 \\
\hline DIC & 180 & 1,000 & 129,000 & 2,300 \\
\hline DOC & 24 & 1,000 & 83,000 & 1,500 \\
\hline $\mathrm{TC}$ & 228 & 2,820 & 260,000 & 4,640 \\
\hline $\mathrm{PNt}$ & 2.8 & 63 & 4,300 & 75 \\
\hline PNf & 2.7 & 42 & 3,500 & 61 \\
\hline $\mathrm{PNc}$ & $<1.0$ & 21 & 800 & 14 \\
\hline $\mathrm{NO}_{3}{ }^{-}-\mathrm{N}$ & 17 & 77 & 13,000 & 220 \\
\hline $\mathrm{NO}_{2}^{-}-\mathrm{N}$ & $<1.0$ & 2.1 & 130 & 2.3 \\
\hline $\mathrm{NH}_{4}{ }^{+}-\mathrm{N}$ & $<1.0$ & 16 & 960 & 17 \\
\hline DON & 2.0 & 99 & 7,200 & 130 \\
\hline $\mathrm{TN}$ & 24 & 194 & 26,000 & 370 \\
\hline
\end{tabular}

We additionally estimated that in both the medium and high flow periods together, the PSR loads to the ocean accounted for: $75 \%$ of the annual discharge, $91 \%$ of the total suspended sediments, $87 \%$ of the particulate organic carbon, $85 \%$ of the particulate organic nitrogen, $74 \%$ of the total dissolved organic carbon, and $78 \%$ of the total dissolved nitrogen.

The Paraíba do Sul River C and N loads to the ocean were compared with other river loads across the world (Table 5) and was observed that the PSR annual water discharge represented only $0.072 \%$ of the total annual discharge of the main world rivers (Meybeck, 1993 ) and $0.39 \%$ of the estimated annual discharge of the South American rivers, which include the Amazon and Orinoco basins (Milliman and Meade, 1983).

The PSR water output occurred along a point of the southeastern Brazilian coastline that is situated between the output of the São Francisco River Basin to the north and the output of the Paraná-Prata River Basin to the south direction. Only these two rivers were considered by Milliman and Meade (1983) for annual output discharge estimations for the east and southeast regions of South America. The Paraíba do Sul River Basin, however, was not considered in this estimate. However, as shown in Table 5, the PSR accounted for $28 \%$ of the assumed 
FIGUEIREDO, R. de O.; OVALLE, A. R. C.; REZENDE, C. E. de.; MARTINELLI, L. A. Carbon and Nitrogen in the Lower Basin of the Paraíba do Sul River, Southeastern Brazil: Element fluxes and biogeochemical processes. Ambi-Agua, Taubaté, v. 6, n. 2, p. 7-37, 2011. (doi:10.4136/ambi-agua.183)

discharge for the rivers in the Eastern South America and for 6\% the Southeastern South America (Table 5). Besides the PSR, other medium-sized and small watersheds are often not considered in global riverine fluxes calculations published in the specialized literature (Hope et al. 1994, Meybeck, 1993, Milliman and Meade, 1983). Our results from the PSR show that the lack of studied medium-sized and small watersheds situated along the east coast of Brazil may result in a significant underestimate of riverine loads to the South Atlantic Ocean.

Table 5. Riverine discharge (in $\mathrm{km}^{3}$ year ${ }^{-1}$ ), TSS, $\mathrm{C}$ and $\mathrm{N}$ fluxes (in $10^{6} \mathrm{Mg}_{\text {year }}{ }^{-1}$ ) to the ocean. Percent of Paraíba do Sul River (PSR) participation is shown when data was available. (Discharge in $\mathrm{km}^{3}$ year ${ }^{-1}$; TSS, C and $N$ fluxes in $10^{6}$ ton year ${ }^{-1}$ )

(TSS is total suspended sediments, PCt is total of particulate carbon, DIC is dissolved inorganic carbon, DOC is dissolved organic carbon, TC is the total carbon in the particulate and dissolved material, PNt is total of particulate nitrogen, DIN is dissolved inorganic nitrogen, DON is dissolved organic nitrogen, and TN is total nitrogen in the particulate and dissolved material).

\begin{tabular}{|c|c|c|c|c|c|}
\hline & PSR $^{(1)}$ & Global $^{(2)}$ & América do Sul ${ }^{(3)}$ & $\begin{array}{c}\text { Eastern South } \\
\text { America }^{(3)}\end{array}$ & $\begin{array}{l}\text { Southeastern } \\
\text { South America }\end{array}$ \\
\hline \multirow{2}{*}{ Discharge } & \multirow{2}{*}{27} & 37400 & 6897 & 97 & 470 \\
\hline & & $0,072 \%$ & $0,39 \%$ & $28 \%$ & $6 \%$ \\
\hline \multirow{2}{*}{ TSS } & \multirow{2}{*}{1,600} & 18000 & 1788 & 28 & 154 \\
\hline & & $0,009 \%$ & $0,09 \%$ & $6 \%$ & $1 \%$ \\
\hline \multirow{2}{*}{ PCt } & \multirow{2}{*}{0,048} & 342 & & & \\
\hline & & $0,014 \%$ & & & \\
\hline \multirow{2}{*}{ DIC } & \multirow{2}{*}{0,129} & 381 & & & \\
\hline & & $0,034 \%$ & & & \\
\hline \multirow{2}{*}{ DOC } & \multirow{2}{*}{0,083} & 298 & & $0,820^{(4)}$ & \\
\hline & & $0,028 \%$ & & $10 \%$ & \\
\hline \multirow{2}{*}{ TC } & \multirow{2}{*}{0,260} & 1021 & & & \\
\hline & & $0,025 \%$ & & & \\
\hline \multirow{2}{*}{ PNt } & \multirow{2}{*}{0,004} & 21 & & & \\
\hline & & $0,019 \%$ & & & \\
\hline \multirow{2}{*}{ DIN } & \multirow{2}{*}{0,014} & 7,75 & & & \\
\hline & & $0,181 \%$ & & & \\
\hline \multirow{2}{*}{ DON } & \multirow{2}{*}{0,007} & 13,5 & & & \\
\hline & & $0,047 \%$ & & & \\
\hline \multirow{2}{*}{ TN } & \multirow{2}{*}{0,026} & 42,25 & & & \\
\hline & & $0,059 \%$ & & & \\
\hline
\end{tabular}

(1) This Study; (2) Meybeck (1993); (3) Milliman and Meade (1983); (4) Bessa and Paredes (1990). 
On the other hand, the contribution of suspended sediment loads from the PSR to the annual global river loads to the ocean was so much smaller than discharge output (Table 4). Despite DOC and DON loads that also were smaller than water discharge, they were larger than particulate carbon and nitrogen loads (PCt and PNt), as well as the total suspended sediments load (TSS). This indicated that dissolved organic matter was exported in larger amount to the ocean than the particulate organic matter. The PSR DIC percent load compared to global rivers is even larger than DOC percent values, which also occurred for nitrogen loads being DIN larger than DON. In fact, the annual DIN percent load compared to the global rivers was four times larger than DON, five times larger than DIC and six times larger than DOC loads. This suggests an important nitrate component in the material export by the PSR to the ocean.

Based on these results, we can say that the dissolved material transported by the PSR and the other medium-sized river basins in the East and Southeast of Brazil, especially DIN, needs to be identified in South American load estimates to the Atlantic Ocean. While it is true that for world riverine flux estimates, the PSR material output is very small, the aggregation of the PSR flux loads with approximately 20,000 other medium-sized and small watersheds around the world (i.e., Knoppers et al. 1997) that are not being considered in the global estimates, indicates a severe underestimate in continental riverine flux calculations and an underlying need to update this information. We consider that the contribution of $\mathrm{C}$ and $\mathrm{N}$ riverine fluxes to the global cycles must be seen according to their interactions with the terrestrial productivity, mainly in tropical regions (McDowell and Asbury, 1994) as well as their effects in the marine systems.

\section{CONCLUSION}

In summary, the studied fluvial system tended to present the following biogeochemical pattern through its observed one-year hydrological cycle:

During low discharge period - The river channel behaved as an alkaline environment with higher neutralization capacity, as a result of weathering mainly, with phytoplankton as its main oxygen source, and with larger concentrations of dissolved solids that take part in the oxy-reduction reactions related to $\mathrm{C}$ and $\mathrm{N}$ fluxes.

During high discharge period - The river channel behaved as a neutral environment with smaller neutralization capacity, with physical factors such as the water turbulence as its main oxygen source, and with smaller concentrations of dissolved solids that take part in the oxyreduction reactions related to $\mathrm{C}$ and $\mathrm{N}$ fluxes.

During medium discharge period - The river channel presented intermediate biogeochemical characteristics which were described for low and high discharge conditions.

Additionally it must be said that along the annual hydrological cycle, the redox conditions of the fluvial system can be influenced by the physicochemistry of the water that comes from anthropogenic sources or related to hydrological processes variation and/or biogeochemical variation of the groundwater, or even by the seasonal variation on the dominant populations of the photosynthetic and heterotrophic aquatic organisms.

We concluded that the observed patterns show some indications that land use change, including the growing sugar cane production in the southeastern Brazilian lands, has the potential to increase riverine $\mathrm{C}$ and $\mathrm{N}$ fluxes. From all of the results of the present research, we can say that the studied basin and the other medium-sized river basins in this Brazilian region have a relative importance for $\mathrm{C}$ and $\mathrm{N}$ inputs to the marine and estuarine systems. 


\section{ACKNOWLEDGEMENTS}

The authors would like to thank FENORTE for the PhD scholarship, FAPERJ for the financial support, DNAEE/CPRM/DEHID for the hydrological data, and the Agência Técnica da Bacia do Paraíba do Sul for the information and maps of the studied river basin.

\section{REFERENCES}

ALI, M. M.; SOLTAN, M. E. The impact of three industrial effluents on submerged aquatic plants in the River Nile, Egypt. Hydrobiologia, v. 340, p. 77-83, 1996.

http://dx.doi.org/10.1007/BF00012737

BALlESTER, M. V. R.; VICTORIA, R. L.; KRUSCHE, A. V. Agroenergia e sustentabilidade do solo e da água. In: PRADO, R. B.; TURETTA, A. P. D.; ANDRADE, A. G. (Org.). Manejo e conservação do solo e da água. Rio de Janeiro: EMBRAPA Solos, 2010. p. 215-236.

BAUDER, J. W.; SINCLAIR, K. N.; LUND, R. E. Physiographic and land use characteristics associated with nitrate-nitrogen in Montana Groundwater. J. Environ. Qual., v. 22, p. 255-262, 1993. http://dx.doi.org/10.2134/jeq1993.00472425002200020004x

BIANCHI, T. S.; BASKARAN, M.; DELORD, J.; RAVICHANDRAN, M. Carbon cycling in a Shallow Turbid Estuary of Southeast Texas: the use of plant pigment biomarkers and water quality parameters. Estuaries, v. 20, n. 2, p. 404-415, 1997.

http://dx.doi.org/10.2307/1352353

BILLEN, G. The Phison River System: a conceptual model of C, N and P transformations in the aquatic continuum from land to sea. In: WOLLAST, R.; MACKENZIE, F. T.; CHOU, L. (Org.). Interactions of $\mathbf{C}, \mathbf{N}, \mathbf{P}$ and $\mathbf{S}$ Biogeochemical Cycles and Global Change. Berlin: Springler-Verlag, 1993. p.141-161.

BRAMLEY, R. G. V.; ELLIS, N.; NABLE, R. O.; GARSIDE, A. L. Changes in soil chemical properties under long-term sugar cane monoculture and their possible role in sugar yield decline. Aust. J. Soil Res., v. 34, p. 967-984, 1996.

http://dx.doi.org/10.1071/SR9960967

BRASIL. Ministério de Minas e Energia. Departamento Nacional de Águas e Energia Elétrica; DB Environment. Projeto Paraíba do Sul: relatório principal da fase B. Rio de Janeiro, 1995. 188p.

BRASIL. Ministério de Minas e Energia. Departamento Nacional de Produção Mineral. Projeto RADAMBRASIL: levantamento de recursos minerais, folhas SF.23/24: Rio de Janeiro/Vitória; geologia, geomorfologia, pedologia, vegetação e uso potencial da terra. Rio de Janeiro, 1983. 780p. 6 mapas escala 1:250.000 (Levantamento de Recursos Naturais, 32).

BRUNKE, M.; GONSER, T. The ecological significance of exchange processes between rivers and groundwater. Freshwater Biology, v. 37, p. 1-33, 1997. http://dx.doi.org/10.1046/j.1365-2427.1997.00143.x 
CALASANS, C. V. C. Origem e dinâmica da matéria orgânica em um sistema fluviolacustre da região norte fluminense. 1998. 120f. Tese (Doutorado em Biociências e Biotecnologia) - Universidade Estadual do Norte Fluminense, Campos dos Goytacazes, 1998.

CAlasans, C. V. C.; CARvalho, C. E. V.; Ovalle, A. R. C.; CORREIA, V. G.; REZENDE, C. E. Distribuição do carbono orgânico dissolvido na porção inferior do Rio Paraíba do Sul, Rio de Janeiro. In: CONGRESSO BRASILEIRO DE GEOQUÍMICA AND III CONGRESSO DE GEOQUÍMICA DOS PAÍSES DE LÍNGUA PORTUGUESA, 5., 23-27 out. 1995, Niterói. Proceedings... Niterói: SBGq, 1995. 1 CD-ROM.

CARMOUZE, J. P. O metabolismo dos ecossistemas aquáticos: fundamentos teóricos, métodos de estudo e análises químicas. São Paulo: Edgard Blücher, 1994. 253p.

CARVALHO, C. E. V. Distribuição espacial, temporal e fluxo de metais pesados na porção inferior da bacia de drenagem do Rio Paraíba do Sul, RJ. 1997. 164f. Tese (Doutorado em Geoquímica) - Universidade Federal Fluminense, Niterói, 1997.

CARVAlHO, C. E. V.; OVALlE, A. R. C.; REZENDE, C. E.; ARAGON, G. T.; CASTRO, S. S. G.; FIGUEIREDO, R. O. et al. Dinâmica de amônia, nitrito, nitrato, fosfato e sílica em três situações de vazão (alta, média e baixa) do Rio Paraíba do Sul, RJ, em sua porção inferior em 1994/95. In: CONGRESSO BRASILEIRO DE GEOQUÍMICA, III CONGRESSO DE GEOQUÍMICA DOS PAÍSES DE LÍNGUA PORTUGUESA, 5., 23-27 out. 1995, Niterói. Proceedings... Niterói: SBGq, 1995. 1 CD-ROM.

CLAIR, T. A.; POLLOCK, T. L.; EHRMAN, J. M. Exports of carbon and nitrogen from rivers basins in Canada's Atlantic Provinces. Global Biogeochem. Cycles, v. 8, n. 4, p. 441-450, 1994. http://dx.doi.org/10.1029/94GB02311

CORRELL, D. L.; JORDAN, T. E.; WELLER, D. E. Nutrient Flux in a Landscape: effects of coastal land use and terrestrial community mosaic on nutrient transport to coastal waters. Estuaries, v. 15, n. 4, p. 431-442, 1992. http://dx.doi.org/10.2307/1352388

COSTA, H.; FREITAS, E. Especial: Paraíba do Sul - Quase um Milagre. Bio, v. 2, p. 8-19, 1989.

COSTA, G. Caracterização histórica, geomorfológica e hidráulica do estuário do Rio Paraíba do Sul. 1994. 97f. Dissertação (Mestrado em Engenharia Oceânica) Universidade Federal do Rio de Janeiro, Rio de Janeiro, 1994.

DEGENS, E. T.; KEMPE, S.; RICHEY, J., Biogeochemistry of major world rivers (SCOPE 42). Chichester: John Wiley \& Sons, 1991. 356p.

DEVOL, A. H.; FORSBERG, B. R.; RICHEY, J. E.; PIMENTEL, T. P. Seasonal variations in chemical distributions in the Amazon (Solimões) River: a multiyear time series. Global Biogeochem. Cycles, v. 9, n. 3, p. 307-328, 1995. http://dx.doi.org/10.1029/95GB01145

ELSENBEER, H.; WEST, A.; BONNEL, M. Hydrologic pathways and stormflow hydrochemistry at South Creek, Northeast Queensland. J. Hydrol., v. 162, p. 1-21, 1994. http://dx.doi.org/10.1016/0022-1694(94)90002-7 
FERRIER, R. C.; WALKER, T. A. B.; HARRIMEN, R.; MILLER, J. D.; ANDERSON, H. A. Hydrological and hydrochemical fluxes through vegetation and soil in the Allt A'Mharcaidh, Western Cairngorms, Scotland: their effect on streamwater quality. J. Hydrol., v. 116, p. 251-266, 1990. http://dx.doi.org/10.1016/0022-1694(90)90126-I http://dx.doi.org/10.1023/A:1005097324154

GARÁDI, P.; ARAÚJO, O. J.; FARIAS, C. G. C.; GALVÃO, I. A.; WOYNAROVICH, E. Utilização da piscicultura como filtro biológico para o Vinhoto (Vinhaça de Melaço): informações preliminares. In: COMPANHIA DE DESENVOLVIMENTO DO VALE DO SÃO FRANCISCO. Estudos de piscicultura. Brasília, 1988. p. 37-71.

GOlTERMAN, H. L.; CLYMO, R. S.; OHNSTAD, M. A. M. Methods for physical and chemical analysis of fresh waters. Oxford: Blackwell Scientific Publications, 1978. $215 p$.

GRAN, G. Determination of equivalent point in potentiometric titration. Analyst, v. 77, p. 661-671, 1952. http://dx.doi.org/10.1039/an9527700661

HAYCOCK, N. E.; BURT, T. P. Role of floodplain sediments in reducing the nitrate concentration of subsurface run-off: a case study in the cotswolds, UK. Hydrological Processes, v. 7, p. 287-295, 1993. http://dx.doi.org/10.1002/hyp.3360070306

HEDGES, J. I. Compositional indicators of organic acid sources and reactions in natural Environments. In: PERDUE, E. M.; GJESSING, E. T. (Ed.). Organic acids in aquatic ecosystems. Chichester: John Wiley \& Sons, 1990. p. 43-63.

HEDGES, J. I. Global biogeochemical cycles: progress and problems. Mar. Chem., v. 39, p. 67-93, 1992. http://dx.doi.org/10.1016/0304-4203(92)90096-S

HEDGES, J. I.; COWIE, G. L.; RICHEY, J. E.; QUAY, P. D.; BENNER, R.; STROM, M.; FORSBERG, B. R. Origins and processing of organic matter in the Amazon River as indicated by carbohydrates and amino acids. Limnol. Oceanogr., v. 39, n. 4, p. 743761, 1994. http://dx.doi.org/10.4319/1o.1994.39.4.0743

HOPE, D.; BILLETT, M. F.; CRESSER, M. S. A review of the export of carbon in river water: fluxes and processes. Environmental Pollution, v. 84, p. 301-324, 1994. http://dx.doi.org/10.1016/0269-7491(94)90142-2

HOPE, D.; BILLETT, M. F.; CRESSER, M. S. Exports of organic carbon in Two River Systems in NE Scotland. J. Hydrol., v. 193, p. 61-82, 1997.

http://dx.doi.org/10.1016/S0022-1694(96)03150-2

HUDON, C.; MORIN, R.; BUNCH, J.; HARLAND, R. Carbon and nutrient output from the Great Whale River (Hudson Bay) and a comparison with other rivers around Quebec. Can. J. Fish. Aquat. Sci., v. 53, p. 1513-1525, 1996. http://dx.doi.org/10.1139/f96-080

JORDAN, T. E.; WELLER, D. E. Human contributions to terrestrial nitrogen flux. BioScience, v. 46, p. 655-664, 1996. http://dx.doi.org/10.2307/1312895

KEENEY, D. Sources of nitrate to ground water. CRC Critical Reviews in Environmental Control, v. 16, n. 3, p. 257-304, 1987. http://dx.doi.org/10.1080/10643388609381748 
KNOPPERS, B.; BALTZER, W.; KÄHLER, P.; CARNEIRO, M. E. R.; MENDOZA, U. N.; VO $\beta$, M. et al. Transport mechanisms biogenic matter in the shallow coastal zones of the Paraíba do Sul and Doce Rivers, East Brazil. In: WORKSHOP JOINT OCEANOGRAPHIC PROJECTS JOPS, 2., 12-15 ago. 1997, Recife. Proceedings... Bremen: Center for Tropical Marine Ecology, 1997. p. 20.

LACERDA, L. D.; REZENDE, C. E.; MARTINELLI, L. A.; OVALLE, A. R. C.; MOZETO, A.; NOGUEIRA, F. et al. Composição isotópica de carbono em componentes de um ecossistema de manguezal na Baía de Sepetiba, Rio de Janeiro. Ciência e Cultura, v. 38, p. 1714-1717, 1986.

LACERDA, L. D.; CARVALHO, C. E. V.; REZENDE, C. E.; PFEIFFER, W. C. Mercury in sediments from the Paraíba do Sul River continental shelf, S.E. Brazil. Marine Pollution Bulletin, v. 26, n. 4, p. 220-222, 1993. http://dx.doi.org/10.1016/0025326X(93)90626-U

LOWRANCE, R. Nitrogen outputs from a field-size agricultural watershed. J. Environ. Qual., v. 21, p. 602-607, 1992.

http://dx.doi.org/10.2134/jeq1992.00472425002100040013x

MACKENZIE, F. T.; VER, L. M.; SABINE, C.; LANE, M.; LERMAN, A. C, N, P, S global biogeochemical cycles and modeling of global change. In: WOLLAST, R.; MACKENZIE, F. T.; CHOU, L. (Org.). Interactions of C, N, P and S Biogeochemical Cycles and Global Change. Berlin: Springler-Verlag, 1993. p.1-61.

MALLE, K-G. Cleaning up the River Rhine. Scientific American., Jan., p. 54-59, 1996.

MARGALEF, R. Ecologia. Barcelona: Ediciones Omega, 1986. 951p.

MARTINELLI, L.A.; FORSBERG, B. A.; VICTORIA, R. L.; DEVOL, A. H.; MORTATTI, J.; FERREIRA, J. et al. Sediment load in the Madeira River. In: DEGENS,. E. T.; KEMPE, S.; EISMA, D. Transport of Carbon and Other Minerals in Major Rivers. Hamburg: SCOPE/UNEP, 1993. v. 74, p. 41-54.

MARTINELli, L. A.; VICTORIA, R. L.; MATSUI, E.; FORSBERG, B. A.; MOZETO, A. A. Utilização das variações naturais de $\delta^{13} \mathrm{C}$ no estudo de cadeias alimentares em ambientes aquáticos. Acta Limnol. Brasil., v. 2, p. 859-882, 1988.

MCDOWELL, W. H.; ASBURY, C. E. Export of carbon, nitrogen, and major ions from Three Tropical Montane Watersheds. Limnol. Oceanogr., v. 39, n. 1, p. 111-125, 1994. http://dx.doi.org/10.4319/lo.1994.39.1.0111

MCCLAIN, M. E.; ELSENBEER, H. Terrestrial inputs to Amazon streams and internal biogeochemical processing. In: MCCLAIN, M. E.; ELSENBEER, H. Biogeochemistry of the Amazon Basin. New York: Oxford University Press, 2001. p. 185-208.

MEADE, R. H. Suspended sediments in the Amazon River and Its triburaries in Brazil during 1982-84. Denver: USGS, 1985. 41p.

MEYBECK, M. C, N, P and S in rivers: from sources to global inputs. In: WOLLAST, R.; MACKENZIE, F. T.; CHOU, L. (Org.). Interactions of $\mathbf{C}, \mathbf{N}, \mathbf{P}$ and $\mathbf{S}$ Biogeochemical Cycles and Global Change. Berlin: Springler-Verlag, 1993. p.163193. 
MILLIMAN, J. D.; MEADE, R. H. World-wide of river sediment to the oceans. Journal of Geology, v. 91, p. 1-21, 1983. http://dx.doi.org/10.1086/628741

MOLDAN, B.; CERNÝ, J. Biogeochemistry of small catchments: a tool for environmental research. Chichester: John Wiley \& Sons, 1994. 419p.

MULHOLLAND, P. J.; HILL, W. R. Seasonal patterns in streamwater nutrient and dissolved organic carbon concentrations: separating catchments flow path and in-stream effects.

Water Resour. Res., v. 33, n. 6, p. 1297-1306, 1997.

http://dx.doi.org/10.1029/97WR00490

NUSH, E. A.; PALME, G. Biologische methoden für die praxis der Gewisseruntersuchung. 1Bestimmung des chlorophyll a und phaepigmentgehaltes in Oberflächenwasser. GWF, v. 116, n. 12, p. 562-565, 1975.

Ovalle, A. R. C.; CARVAlho, C. E. V.; REZENDE, C. E. R.; Silva, C. F.; SALOMÃO, M. S. M. B.; MOLISANI, M. M. Dissolved nutrients fluxes in Paraíba do Sul River, Rio de Janeiro, Brazil. J. Conf. Abs., v.2, n. 2, p.264, 1997.

PEREIRA, W. E.; HOSTETTLER, F. D. Nonpoint source contamination of the Mississippi River and Its tributaries by herbicides. Environ. Sci. Technol., v. 27, n. 8, p. 1542 1552, 1993. http://dx.doi.org/10.1021/es00045a008

REES, R. M.; PARKER-JERVIS, F.; CRESSER, M. S. Soil effects on water chemistry in three adjacent upland streams at Glendye in Northeast Scotland. Wat. Res., v. 23, n. 4, p. 511-517, 1989. http://dx.doi.org/10.1016/0043-1354(89)90143-7

REZENDE, C. E. Origem, transporte e destino da matéria orgânica na interface fluviomarinha, sob diferentes condições de uso do solo e sua relação com o trânsito de poluentes metálicos na Baía de Sepetiba - RJ. 1993. 193f. Tese (Doutorado em Biofísica) - Universidade Federal do Rio de Janeiro, Rio de Janeiro, 1993.

RICHEY, J. E.; VICTORIA, R. L. C, N and P export dynamics in The Amazon River. In: WOLLAST, R.; MACKENZIE, F. T.; CHOU, L. (Org.). Interactions of C, $\mathbf{N}, \mathbf{P}$ and $\mathbf{S}$ biogeochemical cycles and global change. Berlin: Springler-Verlag, 1993. p.123-139.

RICHEY, J. E.; HEDGES, J. I.; DEVOL, A. H.; QUAY, P. D.; VICTORIA, R.; MARTINELLI, L. et al. Biogeochemistry of carbon in the Amazon River. Limnol. Oceanogr., v. 35, n. 2, p. 352-371, 1990. http://dx.doi.org/10.4319/1o.1990.35.2.0352

RICHEY, J. E.; MELACK, J. M.; AUFDENKAMPE, A. K.; BALLESTER, V. M.; HESS, L. L. Outgassing from Amazonian rivers and wetlands as a large tropical source of atmospheric CO2. Nature, v. 416, p. 617-620, 2002. http://dx.doi.org/10.1038/416617a

RIMAWI, O.; EL-NAGA, A.; SALAMETH, E. Hydrochemical characteristics of groundwater resources in the northeastern part of the Jordan Valley, Jordan. Dirasat, v. 19, n. 1, p.87-118, 1992.

RITTER, W. F. Reducing impacts of nonpoint source pollution from agriculture: a review. J. Environ. Sci. Health, v. 23, n. 7, p. 645-667, 1988.

http://dx.doi.org/10.1080/10934528809375441 
SALOMÃO, M. S. M. B. Dinâmica do material particulado em suspensão e metais pesados associados na porção inferior do Rio Paraíba do Sul, Rio de Janeiro. 1997. 30f. Dissertação (Mestrado em Biociências e Biotecnologia) - Universidade Estadual do Norte Fluminense, Campos dos Goytacazes, 1997.

SEITZINGER, S. P. Linkages between organic matter mineralization and denitrification in Eight Riparian Wetlands. Biogeochemistry, v. 25, p. 19-39, 1994.

http://dx.doi.org/10.1007/BF00000510

SHARP, J. H.; PELTZER, E. T.; ALPERIN, M. J.; CAUWET, G.; FARRINGTON, J. W.; FRY, B. et al. Procedures subgroup report. Mar. Chem., v. 41, p. 37-49, 1993. http://dx.doi.org/10.1016/0304-4203(93)90104-V

SILVA, M. A. L. Dinâmica de nitrogênio e fósforo dissolvidos na porção inferior do Rio Paraíba do Sul, Campos, RJ. 1997. 35f. Dissertação (Mestrado em Biociências e Biotecnologia) - Universidade Estadual do Norte Fluminense, Campos dos Goytacazes, 1997.

Silva, M. A. L.; CALASANS, C. F.; OVAlle, A. R. C.; REZENDE C. E. Dissolved nitrogen and phosphorus dynamics in the lower portion of the Paraiba do Sul River, Campos dos Goytacazes, RJ, Brazil. Brazilian Archives of Biology and Technology, v. 44, n. 4, p. 365-371, 2001. http://dx.doi.org/10.1590/S1516-89132001000400006

STUMM, W.; MORGAN, J. J. Aquatic chemistry: an introduction emphasizing equilibria in natural waters. Chichester: John Wiley \& Sons, 1981.780p.

SVENDSEN, L. M.; KRONVANG, B. Retention of nitrogen and phosphorus in a Danish Lowland River system: implications for the export from the watershed. Hydrobiologia, v. 251, p. 123-135, 1993. http://dx.doi.org/10.1007/BF00007172

SUMMONS, R. E. Biogeochemical cycles: a review of fundamental aspects of organic matter formation, preservation and composition. In: ENGEL, M.; MACKO, S. A. Organic geochemistry: - principles and applications. New York: Plenum Press, 1993. p. 3-21.

TIPPING, E.; MARKER, A. F. H.; BUTTERWICK, C.; COLLET, G. D.; CRANWELL, P. A.; INGRAM, J. K. G. et al. Organic carbon in the Humber Rivers. Sci. Total Environ., v. 194/195, p. 345-355, 1997. http://dx.doi.org/10.1016/S00489697(96)05374-0

TRISKA, F. J.; DUFF, J. H.; AVANZINO, R. J. Patterns of hydrological exchange and nutrient transformation in the hyporheic zone of a Gravel-Bottom Stream: examining terrestrial-aquatic linkages. Freshwater Biology, v. 29, p. 259-274, 1993.

http://dx.doi.org/10.1111/j.1365-2427.1993.tb00762.x

TRISKA, F. J.; KENNEDY, V. C.; AVANZINO, R. J.; ZELLWEGER, G. W.; BENCALA, K. E. Retention and transport of nutrients in a Third-Order Stream in Northwestern California: channel processes. Ecology, v. 70, n. 6, p. 1877-1892, 1989. http://dx.doi.org/10.2307/1938119

TRUMBORE, S. E.; DAVIDSON, E. A.; CAMARGO, P. B.; NEPSTAD, D. C.; MARTINELLI, L. A. Bellowground cycling of carbon in forests and pastures of eastern Amazonia. Global Geochemical Cycles, v. 9, n. 4, p. 515-528, 1995.

http://dx.doi.org/10.1029/95GB02148 
FIGUEIREDO, R. de O.; OVALLE, A. R. C.; REZENDE, C. E. de.; MARTINELLI, L. A. Carbon and Nitrogen in the Lower Basin of the Paraíba do Sul River, Southeastern Brazil: Element fluxes and biogeochemical processes. Ambi-Agua, Taubaté, v. 6, n. 2, p. 7-37, 2011. (doi:10.4136/ambi-agua.183)

VITOUSEK, P. M. Beyond global warming: ecology abd global change. Ecology, v. 75, p. 1861-1876, 1994. http://dx.doi.org/10.2307/1941591

WAICHMAN, A. V. Autotrophic carbon sources for heterotrophic bacterioplankton in a floodplain lake of central Amazon. Hydrobiologia, v. 341, p. 27-36, 1996. http://dx.doi.org/10.1007/BF00012300 